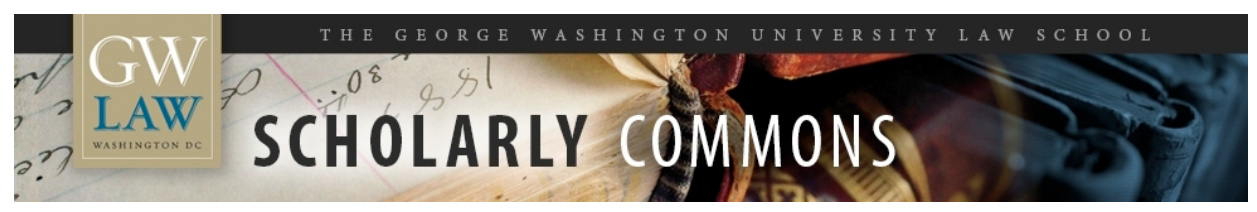

\title{
The Transformation of Originality in the Progressive-Era Debate over Copyright in News
}

Robert Brauneis

The George Washington University Law School, rbraun@law.gwu.edu

Follow this and additional works at: https://scholarship.law.gwu.edu/faculty_publications

Part of the Law Commons

\section{Recommended Citation}

Robert Brauneis, The Transformation of Originality in the Progressive-Era Debate over Copyright in News, 27 Cardozo Arts \& Ent. L.J. 321 (2009).

This Article is brought to you for free and open access by the Faculty Scholarship at Scholarly Commons. It has been accepted for inclusion in GW Law Faculty Publications \& Other Works by an authorized administrator of Scholarly Commons. For more information, please contact spagel@law.gwu.edu. 


\title{
The Transformation of Originality in the Progressive-Era Debate over Copyright in News
}

\author{
Robert Brauneis*
}

In 1991, a unanimous Supreme Court declared in Feist Publications, Inc. v. Rural Telephone Service Co., Inc. ${ }^{1}$ that only those aspects of works which demonstrated a "modicum of creativity" ${ }^{2}$ would be copyrightable. It thus excluded factual representations, which were not "created" but merely "cop[ied] . . . from the world," 3 from copyright protection. That declaration of a bedrock principle of copyright confirmed and extended the unanimous view of an otherwise split Supreme Court in the 1918 case of International News Service v. Associated Press. ${ }^{4}$ Majority and dissenting opinions in INS all expressed the view that information about current events - news - was not copyrightable apart from its literary form. ${ }^{5}$ Yet for the first threequarters of the nineteenth century, the notion that copyright incorporated an originality requirement which excluded factual matter from protection was unknown to Anglo-American law. Courts routinely found infringement of fact-based works, such as maps, charts, road-books, directories, and calendars, on the basis of the copying of their factual content, and concluded that the industry of plaintiffs in gathering and presenting facts - their "intellectual labor" -- should be protected under copyright law. ${ }^{6}$ What caused the transformation in conceptions of originality between the Civil War and World War I?

This article argues that the rise of creativity-based originality in copyright law has strong ties to a previously little-examined episode in copyright history: the debate over legal protection for news in the last decades of the nineteenth century. Until the 1880s, the American news industry remained in a pre-copyright era, and played no part in copyright discourse. Most newspapers were partisan organs that sought financial support at least as much from political sponsors as from sales or advertising. Newspaper editors followed a widespread custom of freely copying text from other newspapers. That custom was acknowledged and encouraged by a massive government subsidy in the form of free postage for newspaper copies that were being

\footnotetext{
* Associate Professor of Law and Co-Director of the Intellectual Property Law Program, The George Washington University Law School; Member, Managing Board, Munich Intellectual Property Law Center. I would like to thank the participants in the September 28, 2007 Symposium on "Feist, Facts, and Functions: IP Protection for Works Beyond Entertainment," co-sponsored by the Intellectual Property Law Program of The George Washington University Law School and the Software and Information Industry Association. For assistance in retrieving petitions and other original documents relating to the news copyright bills of 1884, I would like to thank Rod Ross and William Davis of the Center for Legislative Archives, National Records and Archives Administration. For assistance in locating the briefs of the parties in National Tel. News Co. v. Western Union Co., 119 F. 294 (7 $7^{\text {th }}$ Cir. 1902), I would like to thank the staff of the Chicago office of the National Archives and Records Administration, Great Lakes Region. For comments on drafts of this piece, I would like to thank Ellen Goodman, Michael Carroll, Dawn Nunziato, Lionel Bently, Robert Burrell, the students in my Fall 2008 IP History seminar, and the participants in the October 2008 WIP IP Conference at Tulane University Law School and in the faculty works-in-progress series at The George Washington University Law School.

${ }^{1} 499$ U.S. 340 (1991).

${ }^{2} 499$ U.S. at 362.

${ }^{3} I d$. at 347 .

${ }^{4} 248$ U.S. 215 (1918).

${ }^{5}$ For a discussion of the majority and dissenting opinions in the International News Service case, see notes 181-187 and accompanying text below.

${ }^{6}$ See infra notes 22-60 and accompanying text.
} 
exchanged between editors. Newspaper owners never registered their papers before publication, and thus forsook copyright protection for them.

In the middle decades of 1800s, however, social and technological changes radically changed the structure of the news industry. Political subsidies for newspapers shrank, and newspapers became more heavily dependent on sales and advertising. The introduction of the telegraph provided newspapers with an opportunity to invest in more timely news; yet together with improvements in typesetting, printing, and transportation technology, the telegraph also created an appropriability problem. It shrank the lead-time advantage that newspapers traditionally had relied upon to realize the value of their investment in news, and also exposed them to competition from which they had previously been geographically isolated. At the same time, the new communications technologies led to the emergence of companies and large associations that dominated markets, often with the aid of anti-competitive practices. Prominent among these were the news industry organizations of the Associated Press and the Western Union.

Within this context, the Associated Press, Western Union and others began in the 1880s to press for legal protection of news reports, in both legislative and judicial arenas. On the legislative front, the Associated Press backed an 1884 effort to amend the Copyright Act to provide protection for news items. Opposition to that effort led to the first prominent articulations of the notion that facts are not created by authors, and are therefore not copyrightable subject matter. After that effort failed, the Associated Press and others turned to the courts. Paradoxically, their efforts to seek judicial protection for news ended up reinforcing the creativity-based view of originality, because they resolved for strategic reasons to seek protection outside of federal copyright law, in common law misappropriation, and decided to argue that news was not copyrightable in order to avoid copyright preemption of their common law claims.

Part I of this article sets the stage by briefly considering existing accounts of the rise of creativity-based originality in American law. Part II reviews the intellectual-labor-based model of originality that dominated Anglo-American copyright law in the nineteenth century, and places it in the context of other copyright doctrine of the time. Part III first describes the structure of the American news industry up through the mid-nineteenth century, and explains why that industry operated entirely independently of copyright; in then considers the changes in news industry structure caused by the telegraph and other new technologies, and explains how those changes led the some industry elements to push for legal protection for news. Part IV follows the legislative and judicial campaign for legal protection for news, and traces the development of creativity-based originality rhetoric on both sides of that campaign. Part V draws some conclusions about the broader history of copyright doctrine from this episode.

\section{Do Existing Accounts Explain the Rise of Creativity-Based Originality in} American Law? Mark Rose, Martha Woodmansee, Peter Jaszi and others ${ }^{7}$ have noted the

\footnotetext{
7 See, e.g., Mark Rose, Authors and Owners: The Invention of Copyright 113- 129 (1993); Martha Woodmansee, The Genius and the Copyright: Economic and Legal Conditions of the Emergence of the "Author," 17 EighteenthCentury Std. 425 (1984); Peter Jaszi, Toward a Theory of Copyright: The Metamorphoses of “Authorship,” 1991 Duke L. J. 455.
} 
relationship between the creativity-based view of originality and the ideology of the "romantic author" - the notion that the writer is not merely a craftsman, but "a unique individual uniquely responsible for a unique product." the legal rights of authors, however, were explored in the mid- to late-eighteenth century in both Germany ${ }^{9}$ and England. ${ }^{10}$ Much of the English exploration was in connection with two cases Millar v. Taylor $^{11}$ and Donaldson v. Becket ${ }^{12}$ - that at least by 1834 were extremely well-known in American legal circles, because Wheaton $v$. Peters, ${ }^{13}$ the momentous first copyright decision of the U.S. Supreme Court, concerned similar issues and occasioned frequent references to Millar and Donaldson by litigants and Justices alike. Yet, as will be detailed below in Part II, ${ }^{14}$ none of these debates had any significant influence on the concept of originality in American copyright law before the Civil War. Rather, courts continued to consider works to be original and copyrightable if they were created through the application of independent intellectual labor, even if that labor involved gathering and representing facts rather than expressing anything unique to an author.

Justice O’Connor's opinion in Feist Publications, Inc. v. Rural Telephone Service Co., Inc. ${ }^{15}$ has focused attention on two Supreme Court cases decided, respectively, in 1879 and 1885: the Trade-Mark Cases $^{16}$ and Burrow-Giles Lithographic Co. v. Sarony. ${ }^{17}$ For Justice O'Connor, the Trade-Mark Cases and Burrow-Giles were the first two cases in which the Supreme Court addressed originality, and articulated from the very beginning exactly same view that Feist itself adopts: that the originality requirement precludes any copyright protection for bare representations of fact, because such representations do not exhibit the creativity required by both the Copyright Act and the Constitution. If these cases were indeed the crucial turning points in the treatment of originality in American copyright law, one could argue that the concept of originality evolved because the Supreme Court had to confront for the first time the issues raised by these two cases: respectively, whether the federal constitution empowered Congress to regulate trademarks, and whether it empowered Congress to grant copyright protection to photographs.

This article does not seek to prove that the Trade-Mark Cases and Burrow-Giles have no place in a history of evolving concepts of originality in U.S. copyright law. It does seek to suggest, however, that those cases do not express and implement a change in conception of originality nearly as clearly as it would appear from their treatment in Feist, and that it is therefore possible that another factor made a major contribution to that change. As for the Trade-Mark Cases, the language in Justice Miller's opinion for the Court, passages of which are quoted and paraphrased in Feist, is much more equivocal than might at first appear through modern eyes. When Justice Miller seeks to identify those ingredients that distinguish copyrights

\footnotetext{
${ }^{8}$ Woodmansee, supra n. 7 , at 429.

${ }^{9}$ See id. at 431-448.

${ }^{10}$ See Rose, supra note 7, at 92-112.

114 Burr 2303, 98 E.R. 201 (1769).

124 Burr 2408, 98 E.R. 257; 2 Bro PC 129, 1 E.R. 837 (1774).

1333 U.S. 591 (1834).

${ }^{14}$ See infra notes 22-60 and accompanying text.

15499 U.S. 340 (1991).

16100 U.S. 82 (1879).

17111 U.S. 53 (1884).
} 
(and patents) from trademarks, he does use phrases such as "the creative powers of the mind," "fancy or imagination," and "genius"18 - phrases that one could easily view as representing a creativity-based, romantic author view of originality. In the very same sentences, however, he also uses phrases such as "the fruits of intellectual labor," "work of the brain," and "laborious thought," 19 seemingly without any sense that these phrases are in tension with those referring to "creative powers" and "genius." Given those juxtapositions, there is no reason to believe that Justice Miller would not find whatever "creative powers" are essential to copyright in the "intellectual labor" performed by a mapmaker when measuring and representing the height of a mountain or its latitude and longitude, or performed by the author of a directory when ascertaining the names of the people who live or work at each address in a city. Thus, the TradeMark Cases exhibit, at best, a transitional, ambiguous view of the originality requirement.

At issue in Burrow-Giles was whether the Constitution empowered Congress to protect photography under copyright law. Before photography, the pathway from states of affairs in the world to fixed, copyrightable representations of them always went through the human mind: the minds of mapmakers, directory compilers, and engravers directed the hands that fixed factual representations. Photography took human minds out of that pathway: light, reflected off objects in the world and bent through a lens, fixed an image directly on a tangible, photosensitive medium. Infringement defendants took advantage of this novelty to argue that photographs did not have an author, and therefore could not constitutionally be protected under the Patent and Copyright Clause, which granted Congress the power to protect only authors and inventors. When the issue reached the Supreme Court in 1884, the Court was forced to articulate exactly what it was that made photographs works of authorship. Its answer - that photographs were copyrightable "so far as they are representatives of original intellectual conceptions of the author" 20 - went far towards adopting a creativity-based view of originality, as it placed originality inside the mind of the author.

Yet photography was not destined to remain the driving force behind adoption of a new conception of originality, in part because courts found the copyrightable expression in photographs to be more tightly bound to their representational content than expression and fact were bound in literary works. It was possible to rewrite a news story that had appeared in a competitor's newspaper and claim that one was only taking unprotected facts; it was not possible to "rewrite" a photograph that a competitor had published. And while Burrow-Giles could be read as suggesting that the photographer demonstrated creativity only in physically manipulating the scene in front of the camera, courts came to recognize that the necessary creativity could be found in the decision about where and when to release the shutter, a decision that accompanied the taking of every photograph. As Arthur Weil phrased it in his 1916 copyright treatise, "The elements of thought, arrangement and selection, which appealed to the Court in the Sarony case, are present . . . in the taking of all photographs. Their manifestation is a matter of degree, but their presence, to some extent, no matter how small, is always demonstrable." ${ }^{21}$ If courts find

\footnotetext{
${ }^{18}$ Trade-Mark Cases, 100 U.S., at 94.

${ }^{19}$ Id.

${ }^{20}$ Burrow-Giles Lithographic Co. v. Sarony, 111 U.S. 53, 58 (1884). For an illuminating discussion of BurrowGiles and the effect of photography on copyright law, see Christine Haight Farley, The Lingering Effects of Copyright's Response to the Invention of Photography, 65 U. Pitt. L Rev. 385 (2004).

${ }^{21}$ Arthur William Weil, American Copyright Law 29-30 (1917); see Pagano v. Charles Beseler Co., 234 F. 963, 964 (S.D.N.Y. 1916) (finding originality in a photograph of the New York Public Library because "It undoubtedly
} 
creativity-based originality in all photographs, even those that photojournalistically document the world, and if any work that is not an exact copy of a photograph does not have the audience appeal and thus the commercial value of the original, then the choice between labor-based and creativity-based views of originality will not matter much to photography, and photography will not - and did not - remain a focal point of the debate between those views. Thus, neither romantic author ideology, nor the Trade-Mark Cases, nor Burrow-Giles exclude the possibility that there was another major force at work in the transformation of the concept of originality in copyright law. This article will contend that the changing structure of the news industry, resulting in demands for and objections to protection for news, was that major force.

\section{Originality in Nineteenth-Century Copyright: Intellectual Labor and "Original Sources of Information Open to All”}

For most of the nineteenth century, American publishing, and hence copyright litigation, was dominated by various types of practical, nonfiction works. ${ }^{22}$ Following English precedent, American courts crafted a doctrine of originality that included the factual content gathered in these works as copyrightable subject matter. The 1828 case that first discussed the originality requirement in American copyright law, Blunt v. Patten, ${ }^{23}$ presented an analysis that would be used in dozens of cases throughout the rest of the nineteenth century. In Blunt, Supreme Court Justice Smith Thompson, writing as a circuit judge, considered mapmaker Edmund Blunt's claim that Richard Patten had infringed his copyright in a nautical chart of the coast of northeastern North America. Thompson writes:

The natural objects from which the charts are made are open to the examination of all, and any one has a right to survey and make a chart. And if such surveys and charts are all correct, all will be alike, but no one would complain of his rights having been infringed, and each one may be considered an original chart. A right, in such a subject, is violated only when another copies from the chart of him who has secured the copyright, and thereby availing himself of his labor and skill. ${ }^{24}$

This passage approaches originality as a matter of independent creation. If many people survey the same coastal region and make charts, states Justice Thompson, each of those charts will be original. Conversely, however, if one person copies a copyrighted chart made by another, he will infringe that copyright. That the copyrighted chart merely accurately represents the position of shores and the depth of the water in a particular area is not a defense to infringement. Those representations are part of the protected subject-matter of the map. The representations should be protected because they were the product of the "labor and skill" of the

requires originality to determine just when to take the photograph, so as to bring out the proper setting for both animate and inanimate objects, with the adjunctive features of light, shade, position, etc.).

${ }^{22}$ See Jane Ginsburg, Creation and Commercial Value: Copyright Protection of Works of Information, 90 CoLUM. L. REV. 1865 (1990); Miriam Bitton, Trends in Protection for Informational Works under Copyright Law in the Nineteenth and Twentieth Centuries, 13 Mich. TeleComm. TeCH. L. ReV. 115 (2006).

${ }^{23} 3$ F. Cas. 763 (No. 1580) (1828). This is the report of Blunt's action in equity seeking an injunction; a companion report of Blunt's qui tam action seeking a monetary penalty is found at 3 F. Cas. 762 (No. 1579)(1828).

${ }^{24}$ Blunt, 3 F. Cas. 763, 764-65. For an echo of this logic and rhetoric in dictum in a mid-20 $0^{\text {th }}$-century opinion, see Mazer v. Stein, 340 U.S. 201, 217-18 (1954). 
chart maker. Thus, although Blunt v. Patten does not use the phrase "sweat of the brow,"25 the theory that factual representations should be protected as the intellectual labor of an author enters American copyright law in the very first case to discuss originality.

Justice Thompson cites no sources, but he almost certainly drew his analysis from existing English treatises and cases. Robert Henley Eden's 1821 treatise on the Law of Injunctions, ${ }^{26}$ for example, notes that "maps, charts, road-books, calendars, books of chronology, tables of interest $\& c^{\prime 27}$ are all protected by copyright, and comments that as between two such works on the same subject,

although if the same skill, intellect, and diligence, are applied in the second instance, the public will receive nearly the same information from both works; yet there is no doubt that the latter publisher cannot on that account spare himself the labour and expense of actual survey, and that a court of equity will interfere to prevent a mere republication of a work, which the labour and skill of another person has supplied to the world. ${ }^{28}$

That statement turns out to be an almost exact quote from the 1809 English case of Longman $v$. Winchester, ${ }^{29}$ in which Lord Eldon upheld an injunction against the publication of a "calendar,"30 the contents of which were largely copied from the plaintiffs' work.

25 The phrase "sweat of his own brow" first appeared in conjunction with copyright in Amsterdam v. Triangle Publications, 93 F. Supp. 79 (D. Pa. 1950). It was used to express the somewhat unusual and now-discredited view that the mere combination of features from other maps cannot result in copyright in the compiled map so generated, as copyright in maps could only arise when the mapmaker had himself made observations of the world. In a discussion of this case in 1963, Robert Gorman used the phrase "sweat of the brow." See Robert A. Gorman, Copyright Protection for the Collection and Representation of Facts, 76 Harv. L. Rev. 1569, 1572 (1963). It may surprise some to learn that it was not until 1984 that a court used the phrase in its now well-recognized sense as referring to a theory of originality that does not require creativity. See Financial Information, Inc. v. Moody's Investors Service, Inc. 751 F.2d 501, 506 (2d Cir. 1984).

${ }^{26}$ Robert Henley Eden, A Treatise on the Law of Injunctions (1821).

${ }^{27}$ Id. at 282.

${ }^{28}$ Id. at 282-83. Another revealing discussion is found in George Jeremy's 1828 treatise on equity jurisdiction:

[A]lthough there are some mental productions of such a character, that the author of them must undoubtedly be the original composer, there are others which may de derived from resemblance to some objects of nature or of art, with respect to which it may be extremely difficult to ascertain whether a subsequent publication of the same description of work is a piracy or not. This observation applies to the cases of maps, and of other plates, translations, calendars, and all productions of a similar nature.

George Jeremy, A Treatise on the Equity Jurisdiction of the High Court of Chancery 322 (1828). Note that the works protected by copyright are conceived of as exhibiting an essential unity - they are all "mental productions"; that there are certain types of works which might raise more difficult evidentiary issues with respect to their originality; and that these types of works do not neatly fit the fact/fiction divide - a translation of a work of fiction might pose the same evidentiary issue of originality as a map.

29 16 Ves. Jun. 269, 33 Eng. Rep. 987 (1809). The parallel language in Longman is: "if the same skill, intelligence and diligence, are applied in the second instance, the public would receive nearly the same information from both works: but there is no doubt, that this Court would interpose to prevent a mere republication of a work, which the labour and skill of another person had supplied to the world.” 12 Ves. Jun., at 270; 33 Eng. Rep.. at 987.

${ }^{30}$ In the common usage of the time, a "calendar" was actually a kind of almanac, at the core of which was a directory of important officials, in this case the members of the Houses of Parliament. A good example of such a calendar is "The Court and City Kalendar, or Gentlemen's Register for the Year 1767"; a digitized version of Charles Adams's copy of this publication can be found at http://www.archive.org/details/courtcitykalenda00john. 
Dozens of similar examples from English and American cases and treatises could be cited. The most important example in an American treatise is probably a passage in Joseph Story's influential and widely distributed Commentaries on Equity Jurisprudence, ${ }^{31}$ first published in 1836: "The difficulty [in cases of maps, charts, translations, and road books] is to distinguish, what belongs to the exclusive labors of a single mind, from what is the common source of the materials of the knowledge used by all. . . [A second man] may work on the same original materials; but he cannot exclusively and evasively use those already collected and embodied by another."32 Another important appearance is in George Ticknor Curtis's 1847 Treatise on the Law of Copyright, the first American treatise devoted solely to copyright. Curtis echoes Story, and earlier English cases: "[I]f a person collects an account of natural curiosities . . . or of mere matters of statistical or geographical information, and employs the labor of his mind in giving a description of them, his own description may be the subject of copyright." ${ }^{3}$ He makes it equally clear that copyright in such a work protects, not just stylistic flourishes, but the factual representation itself: "It is equally competent to any other person to compile and publish a similar work. But it must be substantially new and original, like the first work, by resort to the original sources, and must not copy or adopt from the other, upon the notion that the subject is common."34

Courts and commentators continued to use this analysis and logic right into the 1880s. American cases like Lawrence v. Dana (1869), ${ }^{35}$ Farmer v. Calvert Lithographic, Engraving \& Map Publishing Co. (1872), ${ }^{36}$ Banks v. McDivitt (1875), ${ }^{37}$ and List Publishing Co. v. Keller (1887), ${ }^{38}$ and English cases like Kelly v. Morris (1866), ${ }^{39}$ Morris v. Ashbee (1868), ${ }^{40}$ and Hogg v.

\footnotetext{
${ }^{31}$ Joseph Story, Commentaries on Equity Jurisprudence as Administered in England and America (1836).

${ }^{32}$ Id. at 216. Three years later, in Gray v. Russell, 10 F. Cas. 1035 (C.C.D. Mass. 1839) (No. 5728), Justice Story had the opportunity to present the same analysis in a judicial opinion: ("There is no foundation in law for the argument, that because the same sources of information are open to all persons, and by the exercise of their own industry and talents and skill, they could, from all of these sources, have produced a similar work, one party may at second hand, without any exercise of industry, talents, or skill, borrow from another all the materials, which have been accumulated and combined together by him. Take the case of a map of a county, or of a state, or an empire . . $. ”)$.

${ }^{33}$ George Ticknor Curtis, A Treatise on the Law of Copyright 174 (1847). Curtis is borrowing language from Lord Eldon in the 1803 case of Hogg v. Kirby: “ 8 Ves. Jun 215, 32 Eng. Rep. 336 (1803): "I do not see, why, if a person collects an account of natural curiosities, and such articles, and employs the labour of his mind by giving a description of them, that is not as much a literary work as many others.” Id. at 221-222.

${ }^{34} \mathrm{Id}$.

${ }^{35} 15$ F.Cas. 26 (C.C.D. Mass. 1869) (No. 8136) (“[W]here there are certain common objects of information which must, if described correctly, be described in the same words, a subsequent compiler is bound to do for himself that which was done by the first compiler.").

${ }^{36} 8$ F. Cas. 1022 (E.D. Mich. 1872) (No. 4651) ("The defendant, no doubt, had the right to go to the common source of information, and having ascertained those boundaries, to have drawn them upon his map, notwithstanding that in this respect it would have been precisely like plaintiff's map (which of course it would have been if they were both correct). But he had no right to avail himself of this very labor on the part of complainant in order to avoid it himself.”).

${ }^{37} 2$ F. Cas. 759 (1875) (No. 961).

3830 F. 772 (C.C.S.D.N.Y. 1887) ("No compiler of a book such as directories, guide-books, road-books, statistical tables, can acquire, by copyright, a monopoly of the matter published, but the subsequent compiler must investigate for himself from the original sources of information which are open to all.").

${ }^{39}$ L.R. 1 Eq. 697 (1866).

${ }^{40}$ L.R. 7 Eq. 34 (1868).
} 
Scott (1874) ${ }^{41}$ all followed the pattern, as did American treatises like James Appleton Morgan's The Law of Literature (1875) ${ }^{42}$ and Eaton Drone's Treatise on the Law of Property in Intellectual Productions (1879), ${ }^{43}$ and English treatises like Walter Arthur Copinger's Law of Copyright (2d ed. 1881). ${ }^{44}$ The Supreme Court did not have occasion to decide whether copyright protection extended to representations of facts; before 1879, it had only decided seven cases that touched on copyright issues. ${ }^{45}$ As already mentioned above, however, Supreme Court Justices Joseph Story and Smith Thompson did have occasion to do so while riding circuit, and both held that copying of factual content could amount to copyright infringement.

Factual accounts may have been embraced as copyrightable subject matter, but that did not mean that copying a small portion, or even a substantial portion, of someone's factual account would necessarily amount to infringement. Two doctrines concerning the scope of copyright protection are important to understanding why such copying might not constitute infringement. The first is the "new toil" or improvement doctrine, under which a charge of infringement might be avoided by demonstrating that the defendant added substantially new material or otherwise improved an older work, even if he admittedly copied from the old. For example, in the 1847 case of Webb v. Powers, ${ }^{46}$ the court stated that a new compilation may infringe an older one if it uses too much of the latter, "and is not characterized by enough new or improved, to indicate new toil or talent. ${ }^{, 47}$ This doctrine came under attack by the midnineteenth century, and has been contemptuously rejected by jurists of the stature of Learned Hand, ${ }^{48}$ but in a weakened form it still survives as the transformative use factor of fair use analysis. ${ }^{49}$

Second, courts and commentators began to use a "market substitute" approach to copyright infringement, in part as a replacement for the "new toil" doctrine, although the two approaches could in some cases lead to similar results. ${ }^{50}$ L. Ray Patterson and Craig Joyce have

${ }^{41}$ L.R. 18 Eq. 444 (1874).

42 James Appleton Morgan, The Law of Literature 328-331 (1875).

${ }^{43}$ Eaton s. Drone, A Treatise on the Law of Property in Intellectual Productions 201-202 (1879) ("Collections of Well-Known Facts").

${ }^{44}$ Walter Arthur Copinger, The Law of Copyright in Works of Literature and Art (2d ed. 1881).

${ }^{45}$ See Wheaton v. Peters, 33 U.S. 591 (1834); Backus v. Gould, 48 U.S. 798 (1849); Stephens v. Cady, 55 U.S. 528 (1852); Stevens v. Gladding, 58 U.S. 447 (1854); Little v. Hall, 59 U.S. 165 (1855); Paige v. Banks, 80 U.S. 608 (1871); Parris v. Hexamer, 99 U.S. 674 (1878).

4629 F. Cas. 511 (C.C. 1st Cir. 1847) (No. 17,323).

${ }^{47}$ Id. This doctrine is often said to have been wholly repudiated. Most copyright lawyers have probably had occasion to read Learned Hand's witty statement that Yet the principle behind the doctrine survives in fair use analysis to the extent that courts weigh whether or not a claimed fair use is "transformative." Obviously, the "market substitute" and "transformation" issues are not always independent.

${ }^{48}$ See Sheldon v. Metro-Goldwyn Pictures Corporation, 81 F.2d 49, 56 (2d Cir. 1936) ("no plagiarist can excuse the wrong by showing how much of his work he did not pirate").

${ }^{49}$ See, e.g., Campbell v. Acuff-Rose Music, 510 U.S. 569 (1994) ("the goal of copyright, to promote science and the arts, is generally furthered by the creation of transformative works . . . and the more transformative the new work, the less will be the significance of other factors, like commercialism, that may weigh against a finding of fair use"); Sony Corp. v. Universal City Studios, 464 U.S. 417 (1984) (Blackmun, J., dissenting); Blanch v. Koons, 467 F.3d 244 (2d Cir. 2006).

${ }^{50} \mathrm{~A}$ transformation in the nature of a parody, for example, is unlikely to be a market substitute precisely because of the transformation. Other transformations, however - for example,. a "new and improved" version of a book with a few corrections and some added material - could well be market substitutes. 
dubbed the approach a "monopoly of the market" approach. ${ }^{51}$ Importantly, that approach focused heavily on actual markets, not on "potential markets" as the fourth factor in the section 107 fair use inquiry now does. ${ }^{52}$ What copyright protected was the copying of enough of the plaintiff's work that the defendant's work would function as a market substitute for the plaintiff's work. Thus, for example, some abridgments of other works would not infringe, because they would be "much less complete and useful" than the original, would be "suited for a different and humbler class of readers ... . rather than a substitute with the same class." 53

The crucial point here is that neither the "new toil" doctrine nor the "market substitute" doctrine was thought to be limited to factual works. Rather, these doctrines formed part of infringement analysis for the full range of copyrightable subject matter. Thus, for example, a translation of a novel, a work of pure fiction, might equally be found not to amount to infringement, on the ground that it was the product of significant new toil, or was not a market substitute for the novel in its original language. ${ }^{54}$ The result was that these doctrines provided a kind of "safety valve," allowing the copying of significant factual matter that, if prohibited, might call the institution of copyright into question, without singling out factual accounts as needing a special exemption from copyright protection.

One last case deserves extended discussion. In 1829, a year after Blunt v. Patten, Justice Thompson, again riding circuit, decided in a case called Clayton $v$. Stone $e^{55}$ that a "price-current" - a daily newspaper that reported commodity prices - was not a "book" within the meaning of the Copyright Act, which at the time extended copyright protection only to "maps, charts and books." First, reasoned Justice Thompson, the Copyright Act should be read in light of the purpose of copyright as stated in the constitution, namely, to promote the progress of Science. To contribute to science, works had to be of a "permanent and durable character"; ${ }^{56}$ the

\footnotetext{
${ }^{51}$ L. Ray Patterson \& Craig Joyce, Monopolizing the Law: The Scope of Copyright Protection for Law Reports and Statutory Compilations, 36 U.C.L.A. L. Rev. 719, 798 (1989); see Ginsburg, supra note 22, at 1877; Oren Bracha, Owning Ideas 325-329 (2005) (http://www.obracha.net/oi/oi.htm).

${ }^{52}$ See 17 U.S.C. \$107(4) (incorporating "the effect of the use upon the potential market for or value of the copyrighted work" in fair use analysis).

${ }^{53}$ Webb v. Powers, 29 F. Cas. 511 (C.C.D. Mass. 1847) (No. 17,323); see Gray v. Russell, 10 F. Cas. 1035 (C.C.D. Mass. 1839) (per Story, J.) (noting that whether an abridgement infringes the original is a matter of "whether it will, in its present form, prejudice or supersede the original work" and "whether it will be adapted to the same class of readers"). Some early $20^{\text {th }}$ century cases taking the same approach include Social Register Ass'n v. Murphy, 128 F. 116 (C.C.D.R.I. 1904) (noting that a "society" directory might not "constitute [an] invasion" of a general city directory's "general field or purpose”); Sampson \& Murdock Co. v. Seaver-Radford Co., 140 F. 539 (1 $1^{\text {st }}$ Cir. 1905) ("instances may be easily cited where portions of a copyright book may be published for purposes other than those for which the original book was intended"). There was certainly not a uniformity of opinion on the validity of the right of abridgement; Justice McLean, for example, criticizes it in Story v. Holcombe, 23 F. Cas. 171 (1847) (No. 13,497), as resting on reasoning that is "false in fact" because there are "many who are able to buy the original work, that would be satisfied with the abridgement”).

${ }^{54}$ Cf. Stowe v. Thomas, 23 F. Cas. 201, 207 (1853) (No. 13, 514) (holding that a German translation of Harriet Beecher Stowe's novel "Uncle Tom's Cabin" did not infringe her copyright in the novel) ("[I]n questions of copyright, the inquiry is not, whether the defendant has used the thoughts, conceptions, information or discoveries promulgated by the original, but whether his composition may be considered a new work, requiring invention, learning, and judgment, or only a mere transcript of the whole or parts of the original, with merely colorable variations.")

${ }^{55} 5$ F. Cas. 999 (C.C.S.D.N.Y. 1829) (No. 2872).

${ }^{56} I d$.
} 
plaintiff's newspaper was of too "fluctuating and fugitive a form." "57 Second, the copyright act prescribed formalities that seemed so lengthy and cumbersome - most pointedly, a requirement that a copy of the work's registration be published for four weeks in at least one newspaper - that it seemed unlikely that Congress intended them to apply to "a work of so ephemeral a character as that of a newspaper."

It is tempting to read current categories back on to the Clayton case and conclude that the newspaper was denied copyright because its contents - commodity price quotations - were purely factual and thus unoriginal. But the analysis in the case does not proceed along those lines, and, indeed, one would not expect Justice Thompson, the author of Blunt v. Patten, to use such an analysis. Rather, the relevant distinctions were between lasting contributions and ephemeral ones, and between learning and mere industry. An 1848 case which uses the same analysis makes it clear that the Clayton distinctions did not exclude factual matter from copyright protection. In Scoville v. Toland, ${ }^{59}$ Justice John McLean held that labels, which served the purely commercial purpose of identifying goods for sale, were not copyrightable. At the same time, he commented that "lunar tables" - tables showing the dates on which the moon is in its various phases - were copyrightable books even if only printed on a single sheet. That the lunar tables were purely factual was not a matter of which Justice McLean took any note. Rather, he was satisfied that they made a lasting contribution to learning or science, instead of being ephemeral or commercial in character.

The holding of Clayton v. Stone is of uncertain scope - was it supposed to disqualify from copyright only commodity price reports, or did it extend more broadly to cover the contents of all daily newspapers? ${ }^{60}$ There was never any chance to find out, because, in spite of the

${ }^{57} I d$.

${ }^{58} I d$.

${ }^{59} 21$ F. Cas. 893 (1848) (No. 12,553).

${ }^{60}$ There was a distinctly separate business press in the United States in the early 1800s, and Justice Thompson may have taken for granted that he was focusing on business papers, and that that would continue to be a stable, distinct category. Interestingly, time has proven that Justice Thompson was right about the ephemeral nature of such papers. As historian John McCusker has noted, "[i]t seems the peculiar fate of business newspapers that, despite being published in reasonable press runs, they appear to have been less likely to have been preserved than the more general purpose papers.” John J. McCusker, The Demise of Distance: The Business Press and the Origins of the Information Revolution in the Early Modern Atlantic World, 110 The American Historical Review 295, n. 60 (2005).

The holding in Clayton, whatever it was, was gradually eroded over the next half-century. The requirement of publication of four weeks' notice of the registration, emphasized by Justice Thompson, was abolished in 1831. The Clayton decision was heavily criticized by George Ticknor Curtis in his 1847 copyright treatise. See George Ticknor Curtis, A Treatise on the Law of Copyright 108 (1847). By the time Eaton Drone published his treatise in 1879, he could comment (without citing American cases, for there were none) that "[a] more liberal doctrine . . . now prevails. The statutory requirement [of publishing a copy of the registration for four weeks] has been long obsolete. Within the half century that has elapsed since that judgment was rendered, the character of American newspapers has been wholly changed. Much that now appears in them has a permanent literary or scientific value, and as such should be entitled to protection.” Eaton S. Drone, A Treatise on the Law of Intellectual Productions in Great Britain and the United States 229 n.1 (1879). In 1869, an English court had decided that the contents of a newspaper were copyrightable, over argument from the defendant's counsel that newspapers were too ephemeral for copyright (no doubt an argument suggested to counsel by Clayton v. Stone). See Cox v. Land and Water Journal Company, [LR] 9 Eq. 324 (1869). A year later, Walter Copinger cited Cox in the first edition of his treatise on copyright for the proposition that newspapers were copyrightable. See Walter Arthur Copinger, Esq., The Law of Copyright in Works of Literature and Art 224 (1870). By 1886, the Circuit Court for the Southern District of New 
dominance of nonfiction works in American copyright litigation over the next fifty years, no reported case concerned a newspaper. Why was that? One answer is that newspapers might have been deterred from seeking copyright by the burdensome requirements of registration. That answer is not satisfactory, however, because if copyright protection were important to newspapers, they would have sought reform of the registration requirement, and they did not do so until the 1880s. Thus the question remains, and because the answer to this question is crucial to understanding originality doctrine for most of the nineteenth century, this article turns to the task of providing one.

\section{The Nineteenth Century News Industry: Tradition and Change}

A. Pre-Telegraph News Gathering and Dissemination: The Dominance of the Exchange System and the Partisan Press. Throughout the first half of the nineteenth century, newspapers gathered out-of-town news primarily by means of exchanging copies of their papers with newspapers from other cities. Well-established newspapers in large cities would have exchange relationships with dozens and even hundreds of other newspapers. Thus, for example, the Washington, D.C.-based Daily National Intelligencer boasted in 1820: "We receive at our office about three hundred papers, printed in all parts of the United States, from Mobile and New Orleans south, to Detroit north; and from Eastport in the east, to Arkansaw in the west. . . From Upper and Lower Canada, we receive several newspapers ... ."61

This exchange system was promoted and heavily subsidized by the colonial post office, and after independence by the federal post office, which until 1873 carried newspaper exchanges without charge. The practice started by custom in the early 1700s, and was officially sanctioned in a 1758 policy statement by Benjamin Franklin and William Hunter, joint deputy postmasters general for the American colonies. ${ }^{62}$ In 1792, Congress enacted the exchange privilege into federal law, declaring "That every printer of newspapers may send one paper to each and every other printer of newspapers within the United States, free of postage . ..,63

The scale of the resulting exchange system was vast. In 1843, just before the advent of the telegraph, an estimated seven million exchanges were carried by the post office free of charge. $^{64}$ As Richard Kielbowicz has calculated, that meant that, on average, each of the 1600

\footnotetext{
York seemed to assume as a matter of course that an issue of Harper's Weekly, properly registered before publication, was under copyright as a book. See Harper v. Shoppell, 26 F. 519 (C.C.S.D.N.Y. 1886). The particular portion of the periodical at issue was an engraving. Oddly enough, Harper cites Clayton v. Stone as supporting the proposition that a "book" in the copyright sense can be a single sheet of paper (and by extension, can be a newspaper). See id. at 519.

${ }^{61}$ Daily National Intelligencer, Wednesday, August 2, 1820, p.3.

${ }^{62}$ Richard B. Kielbowicz, News Gathering by Mail in the Age of the Telegraph: Adapting to a New Technology, 28 Technology and Culture 26, 29 (1987).

${ }^{63}$ Post Office Act of 1792, 1 U.S. Statutes at Large 238.

${ }^{64}$ Richard B. Kielbowicz, supra note 62, at 30 n. 16. In total, about 39 million newspapers were carried by the U.S. postal system in 1840. See Richard R. John, Recasting the Information Infrastructure for the Industrial Age, in Alfred Dupont Chandler, Nation Transformed by Information: How Information Has Shaped the United States from Colonial Times to the Present 55, 61 (2000). The 32 million that were not exchanges were not carried free of charge, but they were carried at very low rates, as compared to those charged for letters: "newspapers made up as much as 95 percent of the weight of the mail, while accounting for no more than about 15 percent of the revenue." Id.
} 
newspapers in the country was receiving about 4400 exchanges per year, or about a dozen every day. ${ }^{65}$ The weight of these exchanges probably amounted to $15 \%$ or more of the total weight of mail carried by the United States postal system, yet the service was provided completely free of charge, to promote the government policy of spreading news throughout the nation.

Why was news gathered and spread through this informal system of exchanges, rather than through propertization and sale of news items? If the legal structure for propertization was not in place, why didn't newspapers more actively lobby for it? Likely economic explanations include the difficulty of enforcing any such rights, the purely local nature of newspaper publishing (which avoided direct competition with all out-of-town papers), and the lead-time advantage within local markets due to existing typesetting and printing technology. In addition, many newspapers looked as much to partisan subsidies and patronage as to markets for support.

As for the difficulty of enforcement, intercity transportation and hence communication in the pre-telegraph era was slow. Historical geographer Allan Pred has measured the mean lagtime of information between American cities from the 1790s to the 1840s. In 1794, it took about seven days on average for news to travel between New York and Washington, DC, and 45 days for news to travel from New York to Cincinnati. ${ }^{66}$ Twenty-one years later, in 1817, the time-lag from New York to Washington three days; New York to Cincinnati was 19 days; and New York to Chicago was 43 days. ${ }^{67}$ By 1841, with the coming of the railroad, news could travel from New York to Washington in as little as ten hours, ${ }^{68}$ but the average time lag was still longer; the lag between New York and Cincinnati was about eight days, and from New York to Chicago about 10 days.

The slow speed of communication also made it difficult to manage businesses that had locations in many different cities. Almost all newspapers, just as most other businesses at the time, served purely local markets, and therefore did not care if newspapers in other cities copied their stories.

The pre-electronic delivery of news through the transportation system, by means of the physical delivery of newspapers, could also lead to evidentiary difficulties in demonstrating that one newspaper copied another. The same carriage, ship, or railroad that brought one newspaper brought others, and also usually brought people who themselves knew the news from the departure city. Under the exchange system, it was the custom for newspapers to credit the source of news items, both as a courtesy and to enhance credibility; but if newspapers had wanted to conceal the source of their news, it is likely that they often could have.

Many larger cities had more than one newspaper, and there certainly was competition between them. But newspapers could often effectively compete against other local papers

\footnotetext{
${ }^{65} \mathrm{Id}$.

${ }^{66}$ See Allan R. Pred, Urban Systems Development and the Long-Distance Flow of Information Through Preelectronic U.S. Newspapers, 47 Economic Geography 498, 511 (1971). Other important time-lag studies include Donald Lewis Shaw, At the Crossroads: Change and Continuity in American Press News, 1820-1860, Journalism

History, VIII (Summer 1981), 38; Susan R. Brooker-Gross, “Timeliness: Interpretations from a Sample of $19^{\text {th }}$

Century Newspapers,” Journalism Quarterly 58 (Winter 1981), 594-98.

${ }^{67}$ Id. at $513-515$.

${ }^{68}$ Id. at 517.
} 
without propertizing news, given the time and cost of copying. Until the 1884 invention of the linotype machine by Ottmar Mergenthaler, type was set by hand, as it had been for several centuries, and it took hours to set type for a newspaper edition. Printing technology improved dramatically during the nineteenth century - the steam-powered press and the rotary press, invented in 1812 and 1847, respectively, changed top printing speeds from about 300 pages per hour to 20,000 -- but it still took several hours to print and assemble an edition of a newspaper in any volume. In addition, most newspapers worked on a daily schedule; it cost them more to print an "extra" that was released outside the normal schedule. As a result, a newspaper that obtained a "scoop" on a news story usually got a lead-time advantage of at least several hours, and often an entire day. That was likely enough to sell a large number of newspapers, and over time to gain a reputation as a better newspaper. In 1851, Horace Greeley, editor of the New York Tribune, went to London to testify before a parliamentary committee, and gave an account of the lead-time advantage he thought his paper enjoyed:

The fact that certain journals have the earliest news soon becomes notorious, and almost every one wants his newspaper with his breakfast, delivered between the hours of five and half past seven. They take the morning papers to read with their breakfast; and those who take the news after we issue it can not have it in time to deliver it to a very large number in a suitable morning season, and we regard it as of no consequence. ${ }^{69}$

Another important factor in the first half of the nineteenth century was the dominance of the partisan press. Most newspapers were identified with a political party, and were heavily subsidized to serve as the party organ. At every level and from every branch of government, newspaper owners received lucrative printing contracts from the party in power. For example, from 1819 to 1846, each house of Congress elected a printer to publish its proceedings; the contracts, which went to the publishers of such newspapers as the National Intelligencer, the Globe, and the Madisonian, carried profit margins of 20 to 55 percent. ${ }^{70}$ Moreover, members of Congress had franking privileges - the ability to use the postal system free of charge - and frequently used it to send favored newspapers for free across the country. ${ }^{71}$ Over in the executive branch, President Andrew Jackson awarded printing contracts to Jacksonian

${ }^{69}$ Frederic Hudson, Journalism in the United States from 1690 to 1872, p. 542 (1873) (Hudson reprints generous excerpts of the transcript of Greeley's testimony). Greeley also acknowledges that, in the case of important news, the Tribune would take precautions to ensure that no copy of the story left the hands of its confidential agents until the moment that the printed copies of the newspapers were distributed at 5:00 a.m. See id.

Greeley's comments are echoed in a later New York Times article:

Priority of publication is so enormous an advantage in the business of printing news, that when this advantage is secured the newspaper that has secured it can afford to look with complacent indifference upon copyists. There is nothing, for example, to prevent a man from establishing a paper to be published here in New-York at noon, or even in the early forenoon, which shall contain all the news of all of the morning papers and shall be sold for a tenth part of what all the morning papers cost. Nobody has ever done this, because nobody has ever thought that such an enterprise would pay. News once printed is abandoned by the original publisher, who has already made his profit from it, to whoever may choose to reproduce it.

“Copyright in News,” New York Times, February 2, 1884, p. 4; see The Milwaukee Sentinel (Milwaukee, WI), February 22, 1884, p. 3 ("There is such an advantage in priority of publication that no enterprising journal will ask for special protection.”).

${ }^{70}$ See Gerald J. Baldasty, The Commercialization of News in the Nineteenth Century 20 \& 20 n. 68 (1992).

${ }^{71}$ Id. at 20 
newspapers, not only in Washington, D.C., but in Louisville, Boston, Philadelphia, Concord and Columbia. $^{72}$ He also appointed editors of favored newspapers to patronage positions, of which the most popular was postmaster; between 50 and 60 newspaper editors around the country received patronage jobs. ${ }^{73}$ Support of partisan newspapers was just as common at the state and local level. ${ }^{74}$ Newspapers of the era thus tended to be focused on politics and political news, ${ }^{75}$ and sought their rewards more from governments and political parties than from subscribers, single-copy purchasers, or advertisers. In this respect, newspaper editors were like composers of just a few generations before - they looked to patrons rather than markets as their primary source of support. $^{76}$

The end result of these technological and social conditions was that newspapers had little or no need for copyright, and embraced a culture of copying. It would thus be a mistake to conclude that the placement of the newspapers outside of the copyright system was the result of a single judicial decision like Clayton $v$. Stone, or of a single statutory requirement like that of registration. Undoubtedly, registering each daily issue of a paper could amount to a significant expense, and several authors mention the inconvenience of registration as a reason why newspapers were not copyrighted. For example, in his 1875 treatise, James Appleton Morgan wrote that "[t]he impractability of copyrighting under the statutes each succeeding issue of a newspaper, renders them somewhat independent of the laws of copyright, though there is no reason why each successive issue should not be duly entered according to act of congress, if the proprietor should desire to do so."77 Four years later, in 1879, Eaton Drone chimed in: "In the case of a daily newspaper, [registering each issue] will be found inconvenient and perhaps impracticable. In practice, it is not done.”78 Yet in weighing the impracticability of registration,

${ }^{72} I d$.

${ }^{73} \mathrm{Id}$.

${ }^{74}$ Id. at 21-22.

${ }^{75}$ Gerald Baldasty shows the enormous shift in the content of newspapers from the 1830s to the 1890s. In 1831-32, his survey of five metropolitan newspapers reveals that $50.5 \%$ of their column space was devoted to politics, and only $11.6 \%$ to crime and courts, accidents, society and women, and leisure activities; by 1897, his survey of eight metropolitan newspapers found that only $19.3 \%$ was devoted to politics, and $39.1 \%$ to the latter categories. See id. at 123.

${ }^{76}$ On the transition of composers from support by churches and courts to orientation towards markets, see F.M. Scherer, Quarter Notes and Bank Notes: The Economics of Music Composition in the Eighteenth and Nineteenth Centuires (2004).

${ }^{77}$ James Appleton Morgan, The Law of Literature, vol. II, p. 381 (1875).

${ }^{78}$ Eaton S. Drone, A Treatise on the Law of Property in Intellectual Productions 170 (1879).

Unlike daily newspapers, major weekly and monthly periodicals, which often featured essays, serial novels, engravings, and commentary rather than news, were often registered. See The New York Times, Nov. 20, 1870, p. 1 (introducing the new Copyright Act of 1870, which for the first time established a single office for registering copyrights in the Library of Congress) ("Nearly or quite all the magazines were copyrighted under the old law, but the copyrighting of newspapers was not practiced. Nor is it now, very generally; still, several weekly newspapers and literary papers are entered regularly-among others, the pictorial papers of Frank Leslie, and the Harper's, the Hearth \& Home, the Ledger, the Christian Union; and the time may not be so very distant when all our important weekly and daily papers will secure in the same way their rights to what they print.”). The first issue of Harper's Weekly was published on January 3, 1857; beginning with the issue of April 9, 1859, each issue displays the statutorily required notice of registration. (The issues of Harper's Weekly published between 1857 and 1912 are available on the HarpWeek website, http://app.harpweek.com/.) Similarly, Frank Leslie's Illustrated Newspaper was first published on December 15, 1855; beginning on April 14, 1857, every issue displays a notice of registration. (The issues of Frank Leslie’s Illustrated Newspaper published between 1855 and 1892 are available in the Gale "Nineteenth Century U.S. Newspapers” database.) 
one has to consider the potential benefits of registration, as well as the burden. The fact was that the potential benefits were slight, so that taking on even a modest burden did not seem worthwhile.

The fact that newspapers, for economic reasons, remained outside of the copyright system, had a significant if completely unnoticed impact on the prevailing intellectual-labor view of the originality requirement for copyright. That view purported to be quite broad in scope: any factual representation was the result of mental labor and was therefore copyrightable, and no one could copy wholesale that representation as a substitute for going out into the world and doing the hard work of gathering the factual details himself. By its own terms, that logic should apply to narrative accounts of current events, as well as non-narrative representations of states of affairs like maps and city directories. In practice, however, so long as newspapers remained outside of copyright, originality doctrine did not have to come to grips with copyright issues concerning such news accounts.

Moreover, the effect of newspapers remaining outside of copyright spread beyond the papers themselves to any historical or biographical account that was not based on first-hand observation, since the great bulk of second-hand accounts could be traced through uncopyrighted newspapers. Thus, for example, in the 1841 case of Folsom v. Marsh ${ }^{79}$ the plaintiffs claimed that the defendants had copied many of George Washington's letters, but they made no claim as to the historical narrative that accompanied the letters and put them into context. Justice Story wrote: "So far as the narrative goes, it is either original, or derived (at least as far as the matter has been brought before the court) from common sources of information, open to all authors." 80 The phrase "common sources of information, open to all authors" was usually used to refer to the world itself, but events that had taken place long ago were as a practical matter no longer "open to all authors." What were still available to authors were newspaper accounts, or histories derived from newspaper accounts. Because they were not under copyright, they were also “common sources of information, open to all authors."

B. Mid-Century Changes in News Gathering and Dissemination: The Telegraph and the Demise of the Party Press. The invention and deployment of the electric telegraph dramatically changed many industries, and the news industry was prominent among them. Telegraph lines began commercial operation in the mid-1840s. Within two decades, they blanketed the country. By 1866, Western Union controlled 37,380 miles of telegraph lines and 2,250 telegraph offices in almost every town and city of any size in the United States. ${ }^{81} 1866$

There are a few scattered mentions of registrations of daily newspapers. See Frederic Hudson, Journalism in the United States from 1690 to 1870, p. 723 (1873) ("Several papers, mostly weekly publications, although we have seen one daily newspaper, regularly appear with [registration notices]"); Richard Rogers Bowker, Copyright: Its History and Its Law 88 (1912) (mentioning that a daily price list of the New York Cotton Exchange was registered every day); Tribune Co. of Chicago v. Associated Press, 116 F. 126, 127 (C.C. Ill. 1900) (the Chicago Daily News had begun to register each daily edition of the newspaper, perhaps in anticipation of litigation); Egbert v. Greenberg, 100 F. 447 (N.D. Cal. 1900) (the proprietors of the "Daily Racing News," plaintiffs in the case, had evidently begun to register that paper).

${ }^{79} 9$ F. Cas. 342 (C.C. Mass. 1841) (No. 4901).

${ }^{80} \mathrm{Id}$. at 347.

${ }^{81}$ See Robert Luther Thompson, Wiring a Continent: The History of the Telegraph Industry in the United States 1832 - 1866, 426 (1947). There were 75,686 miles of wire strung along those lines. Id. 
also marked the completion of the first successful transatlantic cable, ${ }^{82}$ thus enabling telegraphic communication between the Old World and the New. ${ }^{83}$ A transcontinental telegraph line from Chicago to San Francisco had been completed in 1861, eight years before the transcontinental railroad. Through a combination of effects, this revolutionary telecommunications technology enabled and spurred on calls for increased legal protection for news.

First, the speed of communication over long distances made possible the development of geographically dispersed, and hence larger, business organizations. Management in one city could receive reports from and send orders to employees in other cities within minutes, if necessary, and daily interaction could become routine. ${ }^{84}$ Two prime examples of the development of larger organizations were those intimately associated with news gathering and dissemination: Western Union and the Associated Press. By 1866, Western Union became the first industrial monopoly, controlling over $90 \%$ of the telegraph business in the United States. ${ }^{85}$ The Associated Press, founded in 1848 just after the commercialization of the telegraph, underwent several reorganizations in the second half of the nineteenth century, but in one form or another dominated news gathering and dissemination in the United States after the Civil War. Although most individual newspapers remained locally owned, they were members of associations that competed on a national scale. Exchanges of news between members were now centrally controlled, and exchanges of news with non-members were prohibited, on pain of revocation of membership. ${ }^{86}$

Telegraphic communication also made it easier to pursue enforcement actions in places remote from a business's head office - communications between attorney and client allowed for effective pursuit and control of litigation. By the 1890s, the Associated Press was involved in lawsuits against newspapers in New York, Washington, D.C., Minneapolis, Milwaukee, Chicago, and St. Louis, a geographic reach of litigation that would have been unthinkable without communication by telegraph. ${ }^{87}$ Moreover, telegraphic communication would often make it easier to prove that the plaintiff's news dispatch was the source of the defendant's story. The telegraph message carrying the news arrived long before any people who might be carrying it as word-of-mouth, and as long as Western Union and Associated Press were dominant, there were unlikely to be other telegraph lines or news services through which the defendant could have gotten the story.

Second, the telegraph could effectively destroy the lead-time advantage that had previously protected news organizations. Several competitive scenarios irked newspapers that

\footnotetext{
${ }^{82}$ See Annteresa Lubrano, The Telegraph: How Technology Innovation Caused Social Change 9, 155 (1997).

${ }^{83}$ The telegraph was not the first telecommunications technology. Newspapers, governments, and others had been experimenting with carrier pigeons, semaphore systems, and the like. But the telegraph far outstripped these in speed and distance.

${ }^{84}$ Richard Du Boff argues that telegraph use had scale effects, control effects, and intelligence effects that led to dominance of single firms in many markets. See Richard B. DuBoff, The Telegraph in Nineteenth-Century America: Technology and Monopoly, in 26 Comparative Studies in Society and History 571, 573-579 (1984).

${ }^{85}$ See id. at 572.

${ }^{86}$ See Victor Rosewater, History of Cooperative News-Gathering in the United States 260-261 (1930).

${ }^{87}$ See The Law of the Associated Press, Vol. I (1914) (republishing documents from Associated Press litigation against the publishers of the Chicago Inter Ocean, p. 3; the St. Louis Star, p. 89; the New York Sun, p. 286; the Washington News, p. 446; the Minneapolis Tribune, p. 472; and the Milwaukee Daily News and Milwaukee Germania, p. 506).
} 
had spent money to gather news. Large-city newspapers had begun to gain audiences in the surrounding countryside as improved railroad lines made far-flung distribution possible in less than a day. Small-town papers along those railroad lines, however, would arrange for agents to telegraph the news as soon as the big-city papers were available in the big cities, and the smalltown papers could then go to press before the train from the big city arrived. Thus, Frederic Hudson reported in 1873, a "journalist that was desirous of an influence beyond the limits of the city where his newspaper is published" did not always view the telegraph kindly, "especially when he reads an announcement that 'the Elmira (N.Y.) Advertiser publishes telegraph news fifteen hours in advance of the receipt of the New York dailies.",88

Lead-time advantage was also destroyed when telegraphic transmissions cut across time zones. The Associated Press and some of the New York newspapers complained about this scenario in the early 1880s: "The complaint is made that the New York correspondents for newspapers in Chicago and other points west to San Francisco, by reason of the difference of time in their favor, can, without credit, telegraph all there is worth telegraphing from New York to their respective journals. They not only can, but do. One or two San Francisco newspapers, because of this, have given notice of a desire to withdraw from the Associated Press." 89 The facts of International News Service v. Associated Press, ${ }^{90}$ the famous case that ended up in the Supreme Court in 1918 (and to which this Article will return), involve such a scenario. The International News Service was allegedly copying Associated Press news stories as they were published in New York newspapers, and telegraphing them to the west coast, three time zones earlier. West coast newspapers that were INS subscribers could then print the news in time for their morning or evening editions, and compete head-on against their AP-subscriber competitors. $^{91}$

A third scenario involving the loss of lead time arose with the development of "tickers," machines that could print text from a telegraphic signal without the need of a human operator.

\footnotetext{
${ }^{88}$ Frederic Hudson, Journalism in the United States from 1690 to 1872, p. 595 (1873). Another new source of competition for big-city newspapers were the producers of "patent insides" for smaller-town papers - pre-set printing plates that would be shipped out to smaller towns for printing together with local content on the covers. See Galveston Daily News, February 8, 1884, p. 4 ("In Chicago and other cities the patent newspaper fiends take the early morning newspapers, clip them up before daylight, and in the course of a couple of hours have the pith of the news in type for patent insides for country dailies which appear in the afternoon in smaller cities along the lines of the railroad that distribute the larger city papers.”)

${ }^{89}$ Oshkosh Daily Northwestern (Oshkosh, WI), February 29, 1884, p.3 (quoting the Cincinnati Enquirer, February 20, 1884); see The New York Times, February 18, 1884, p. 2 ("The difference in time between points relatively east and west in our vast country enable a publisher enable a publisher who chooses to do so to make use of the enterprise of others. Should the thief at a distant point be enabled by the use of the telegraph to steal the property of those men who have gone to great care and cost to obtain it?") (quoting Henry Watterson, who had been engaged by the Associated Process to lobby for a bill to extend copyright to newspapers, see infra note 96 and accompanying text).

${ }^{90} 248$ U.S. 215 (1918).

${ }^{91}$ Associated Press also claimed that INS was bribing employees of AP member newspapers to give it AP dispatches before they were published. This scenario, involving unauthorized disclosure of unpublished documents that might be considered trade secrets, could in theory also occur without the involvement of the telegraph; one newspaper might bribe an employee of its local competitor to pass news stories to it. The fact that AP has already telegraphed the story to many newspapers made tracing a leak more difficult, however, and the fact that INS was representing many subscribers rather than a single newspaper would likely increase the amount of the bribe it was willing to offer.
} 
Without the need for a human intermediary, telegraphed news began to be distributed directly and continuously to end-user subscribers, who had such machines installed in their offices, shops, hotels, or restaurants. A competing company could have an employee read a ticker tape in a public place or in the office of a conspiring subscriber, and then enter the news dispatches into its own distribution system, which would have its own subscribers. Instead of typesetting and printing, the only action required was telegraphic keying or typing, and there were no editions on a daily cycle, because the ticker tape ran continuously. In such circumstances, lead time could be cut from hours to a minute or less. ${ }^{92}$

Although the telegraph did not have as much effect on the traditional cross-town newspaper rivalry, ongoing technological developments in typesetting and printing were cutting lead time between cross-town rivals, and occasionally the telegraph also had a role to play in those situations. For example, in the 1860s, the San Francisco Bulletin and the Sacramento Union had succeeded in excluding other area papers from gaining access to the transcontinental telegraph lines, and thus excluded them from direct access to news telegraphed from the East Coast. Another San Francisco paper, the Alta California, waited for the Union to be published in Sacramento, and then had an agent telegraph the Union's news over a Sacramento - San Francisco telegraph line. The Alta eventually convinced the Bulletin and the Union to let it join their scheme, but other excluded San Francisco newspapers continued the practice. ${ }^{93}$

Third, although communication by telegraph was of great value to many people, it was also very expensive. The initial capital costs of setting up a telegraph line across hundreds or thousands of miles could be enormous, and operating and maintenance costs were also substantial. While the newspaper exchange system had been heavily subsidized by the federal government through free postal carriage, the telegraph system did not benefit from government largesse on such a scale.

Of course, some of the messages carried by telegraph were private and of value only to particular individuals or businesses; those individuals or businesses who wanted to send or receive them would pay for the privilege. Other messages, such as timely commodity or stock price reports, were particularly valuable to a relatively small group of investors and traders. Those individuals and firms would also pay for that information; channels of communication could be relatively well-protected against unauthorized tapping; authorized recipients could be bound by subscription contracts not to pass it on to others; and enforcement against third parties who were inducing breaches of those contracts could be sought under trade secret law.

That still left a lot of information about current events that was of interest to, and valued by, the general public. How could the cost of gathering and transmitting that information be borne by the public, to whom it was of value? Newspapers had not previously had to face this problem, in part because they were often supported as partisan organs by governments and political parties, and in part because they enjoyed lead-time advantages over copiers. If

\footnotetext{
${ }^{92}$ Such facts formed the basis of the dispute in National Telegraph News Co. v. Western Union Telegraph Co., 119 F. 294 ( $7^{\text {th }}$ Cir. 1902).

${ }^{93}$ See Barbara Cloud, News: Public Service or Profitable Property?, 13 American Journalism 141, 144 (1996) (citing Robert J. Chandler, “The California News-Telegraph Monopoly, 1860-1870,” 58 Southern California Quarterly 459 (1976)).
} 
technological developments cut lead time, social developments cut political patronage. It is not within the scope of this paper to trace those complicated social developments. It is clear, however, that during the middle decades of the nineteenth century, newspapers moved dramatically away from political parties, and began to rely much more on sales and advertising for revenue. ${ }^{94}$ One might therefore see the adoption by Congress in 1846 of a low-bid system for awarding printing contracts as signaling the end of an era. ${ }^{95}$

Thus, arguably, the decline of patronage and lead time left news organizations to deal with a classic problem of appropriability. ${ }^{96}$ Of course, as we will see, opponents of protection for the news strongly disputed the existence of such a problem, and the issue whether any particular level of protection for news or newspapers would optimize the production of news is beyond the scope of this paper. It is clear, however, that some news organizations sought to convince Congress and the courts of the existence of an appropriability problem; that they had a plausible story to tell; and that developments in communications technology made possible a new business model for journalism - the selling or licensing of news stories, rather than informal exchange and sharing - that was more difficult to put into practice without some legal protection for news.

\section{IV: Efforts to Protect News in Congress and the Courts and the Rise of Creativity- Based Originality Rhetoric.}

During the 1880s and 1890s, news organizations like the Associated Press and Western Union (which, although mainly a telegraph company, made occasional forays into the news dissemination business) attempted to gain legal protection for news in both the Congress and the courts. The one serious attempt in Congress took place in 1884. This article will argue that the most important attempt in the courts culminated in a federal court of appeals decision in 1902. In both cases, this paper will argue, those attempts led to the articulation of a creativity-based view of the originality requirement in copyright.

A. The News Copyright Bill of 1884. In late 1883, the Associated Press sent Henry Watterson to Washington, D.C. to seek passage of a bill that would grant short-term protection to articles published in newspapers. ${ }^{97}$ Watterson was the founder and editor of the Louisville Courier-Journal; he had served a partial term in the U.S. House of Representatives in 1876 and 1877, having been elected to serve out the remaining term of a Kentucky Congressman who had died in office.

On March 4, 1884, Senator John Sherman of Ohio introduced “A Bill Granting Copyright in Newspapers."98 Six days later, Representative John Randolph Tucker of Virginia introduced

\footnotetext{
94 These developments are traced in Gerald J. Baldasty, supra note 70, at 36-58.

95 See id. at 42.

${ }^{96}$ On the problem of appropriating gains from innovation and information, see, e.g., Joseph Schumpeter, Capitalism, Socialism, and Democracy (1950); Kenneth J. Arrow, Economic welfare and the allocation of resources for invention, in R. Nelson, The Rate and Direction of Inventive Activity 609 (1962).

${ }^{97}$ Henry Watterson, Marse Henry: An Autobiography, vol. II, p. 104 (1919) [available on Google Books].

${ }^{98}$ S. 1728, $48^{\text {th }}$ Cong., see 15 Cong. Rec. 1578. The full text of the bill was:
}

A Bill Granting Copyright to Newspapers 
an identical bill in the House. ${ }^{99}$ The bills sought to grant newspapers and newspaper associations "the sole right to print, issue and sell for the term of eight hours, dating from the hour of going to press, the contents of [the] newspaper, or the collected news of said newspaper association, exceeding one hundred words." 100 Thus, the rights were granted directly to the newspaper or the association, rather than to the author of the contents; ${ }^{101}$ and they were good for eight hours from going to press.

Newspapers across the United States quickly learned of the bill, and devoted their own column space to engaging in vigorous debate about it. The opponents of the news copyright bill sent scores of petitions to Congress. Entries in the Congressional Record document the receipt of at least 60 separate petitions in opposition, received from citizens of at least 19 of the 38 states then in the Union, and of the Dakota Territory. ${ }^{102}$ Many of those petitions have been preserved in the National Archives. ${ }^{103}$ Most of the petitions opposing the bills were sent on identical printed forms with blank spaces to be filled in with the name, newspaper affiliation, and address of the petitioner, which suggests that there was organized opposition to the bills. By contrast, Congress apparently received only one petition in favor of the bill, though that was from the Southern Press Association, which represented 22 newspaper members. ${ }^{104}$

The bill divided newspapers along four overlapping fault lines. First and most prominently, it divided the "metropolitan" papers - big-city papers with large circulations that could afford to hire their own reporting staffs and to pay to belong to a news association and

Be it enacted by the Senate and House of Representatives of the United States of America in Congress assembled, That any daily or weekly newspaper or any association of daily or weekly newspapers, published in the United States, or any of the Territories thereof, shall have the sole right to print, issue and sell for the term of eight hours dating from the hour of going to press, the contents of said daily or weekly newspaper, or the collected news of said newspaper association exceeding one hundred words.

Section 2. That for any infringement of the copyright granted by the first section of this Act, the party injured may sue in any court of competent jurisdiction, and recover in any proper action the damages sustained by him from the person making the infringement, together with the costs of suit.

Two other copyright bills that have sometimes been mistakenly identified as being related to these are H.R. 7341, $47^{\text {th }}$ Cong., 2d Sess. (introduced Jan. 23, 1883) (Cong. Rec. p. 286), and H.R. 62, 48 ${ }^{\text {th }}$ Cong., see 15 Cong. Rec. 60 (1883). These bills were both entitled "A bill giving copyrights under certain conditions to journalistic articles." However, they were not concerned with granting copyright to newspapers. Instead, they would have allowed a writer whose work had initially been published in an uncopyrighted newspaper to obtain copyright under certain conditions (the conditions included "caus[ing] to be published six times, in the journal or periodical in which said articles originally appeared . . . a notice that [the author] had acquired such copyright protection.”

${ }^{99}$ H.R. 5850, $48^{\text {th }}$ Cong., see 15 Cong. Rec. 1758.

${ }^{100}$ Id. Apparently, drafts of the bill before it was introduced had set the period of exclusivity at 48 hours, and then at 24 hours, before settling on the period of eight hours. See The Saturday Evening Observer, Dunkirk, NY, March 15, 1884, p.1.

${ }^{101}$ In committee hearings on the bill, one of the questions raised was whether Congress had the power under the constitution to grant rights directly to newspapers, since the Copyright Clause refers only to a power to grant exclusive rights to Authors. See The Galveston Daily News, March 20, 1884.

102 See 15 Cong. Rec. 111 (1884) (index listing all of the entries for petitions relating to the bills).

103 They are located in Record Group 233, in folders HR 48A - H 12.5 (Committee on the Judiciary) and HR 48A H 21.3 (Committee on Patents); and in Record Group 46, in folders S 48A - H 14 (Committee on the Library) and S 48A - J6 (Tabled Petitions)..

${ }^{104}$ See id. It is not clear how supportive of the bill the members of the Southern Press Association actually were. The Atlanta Constitution was a member of the Association, but it published a number of statements in opposition to the bills. See The Atlanta Constitution, March 14, 1884, p. 4; The Atlanta Constitution, March 25, 1884 , p. 4. 
receive telegraph dispatches - from the "country press," small-town papers that continued to rely heavily on borrowed material to fill their pages. To the metropolitan papers like the New York Times, "the country newspapers [were] beneath the rule of men with whom the scissors are mightier than the pen"; it and the other metropolitans were victims of the typical "rural editor," who had to "loo[k] back over a career of small piracies." 105 The country press agreed that the news copyright bill pitted them against the metropolitans, but cast the bill in a negative light. It was, according to the Newark Daily Advocate (Newark, Ohio), "a monopoly scheme to force the readers in the smaller towns to depend for their news upon the metropolitan press ring, to the exclusion of the home journals." ${ }^{106}$ As the editor of the Elizabeth Journal (of Elizabeth, New Jersey) argued, "the result of passing such a bill would be to cripple the local press of New Jersey and place the people of that state at the mercy of the New York and Philadelphia papers, which have no interest in the welfare of the small New Jersey towns, and no space in which to discuss the local interests of the numerous places in which they are constantly seeking to encroach upon the preserves of the local press."107

Second, the news copyright bills set the Associated Press and its members (many of whom were the "metropolitan" papers) against the members of the United Press -- at that time a two-year-old competitor of the $\mathrm{AP}^{108}$-- and against independent papers that were not members of either association. The United Press did not itself publicly oppose the bills, ${ }^{109}$ but some of its prominent members did, ${ }^{110}$ and the opposition to the bill was often tied to animosity towards the "monopolies" of the Associated Press and the Western Union. ${ }^{111}$

Third, the bill set afternoon papers, which were often accused of lifting material from morning-paper competitors, against the morning papers that were the alleged victims of the

\footnotetext{
105 The New York Times, Feb. 2, 1884, p. 4.

${ }^{106}$ Newark Daily Advocate (Newark, Ohio), February 19, 1884, p. 1 See Newark Daily Advocate (Newark, Ohio), January 26, 1884, p. 1 ("The object is to promote the circulation of the large metropolitan papers by prohibiting the reproduction of news in the journals of the smaller towns and cities while it still has news value.”).

${ }^{107}$ Oshkosh Daily Northwestern (Oshkosh, WI), February 26, 1884, p. 2.; also reported in Newark Daily Advocate (Newark, OH), Feb. 25, 1884, p. 1.

${ }^{108}$ See Richard A. Schwarzlose, The Nation's Newsbrokers, Vol. II, p. 133, p. 248 table 1 (UP had grown from "barely one hundred subscribers" in 1882 to 166 subscribers in 1884; AP had 425 subscribers in 1883). Schwarzlose portrays the news copyright bill as an effort of the AP to "tackl[e] the UP competition.” Id. at 135.

${ }^{109}$ United Press likely thought that opposition to the bill would cast it in a bad light: "Some opposition was apprehended from the United Press from the supposition being that that organization was to some extent dependent on the published reports of the Associated Press, but not a word in the way of a demurrer has come from that organization, its managers holding that it suffered more from the pilfering of its news by the Associated Press papers than it is benefitted by its having access to the Associated Press reports after they are in print.” Newark Daily Advocate (Newark, OH), Feb. 25, 1884, p. 1.

${ }^{110}$ See, e.g., Boston Daily Globe, March 27, 1884, p.2 (criticizing the news copyright bill and predicting that it would fail: "We are inclined to believe that the Associate Press will have to take its chances with the rest of the journalistic world in getting the news.”); Richard A. Schwarzlose, The Nation's Newsbrokers, supra note 107, p. 133 (describing the Boston Globe as a "mainstay" of the United Press)

${ }^{111}$ See, e.g., Newark Daily Advocate (Newark, OH), Mar. 3, 1884, p. 1. The Daily Advocate quoted a speech by Rep. John Anderson of Kansas at length. Rep. Anderson railed against the monopoly of the Western Union, are argued that it should be nationalized; portrayed Associated Press editors as "censors" whose power to affect public debate dwarfed that of the President as a "tempest” did a "baby’s breath"; and concluded by railing against the news copyright bill, which would extend the power of the Western Union over the country press. Id.
} 
borrowing. ${ }^{112}$ Similarly and fourthly, it set East Coast papers, which were the first to go to press every day, against western papers located in time zones that lagged one to three hours behind the East Coast, putting them in a position to borrow material from published East Coast papers.

For purposes of this article, the important thing about this debate is to note how opponents of the bill contested it, and how supporters defended it. One of the most prominent arguments used against the bill articulated and depended upon a creativity-based view of originality. For example, the printed petition against the bill, copies of which were sent by dozens of newspaper editors to Congress, asked "What is news? The statement of facts, the history of current events. Can any one create or invent a fact or event? If he cannot create or invent a fact or event, how can he copyright it?"113 Similarly, the Newark Daily Advocate of Newark, Ohio reported a speech by Representative John Anderson of Kansas, railing against the bills: "While there may be a possible ground for copyrighting the editorial, as the product of the editor's brain, what ground is there for copyrighting, say, election returns, or the news of Garfield's murder! Does the editor create them in the sense that an author creates a book? In my mind the measure is a glaring wrong, glittering with impertinence . ...,114

Almost two decades after Feist Publications, Inc. v. Rural Telephone Service Co, Inc., ${ }^{115}$ the contention that facts are not copyrightable because they aren't created by authors appears perfectly familiar to us. Yet in 1884, existing case law and treatises did not contain such reasoning. Courts and treatise writers uniformly supported the view that a work which presented facts that had been gathered by observation of the world should be protected under copyright law. However, they had not been faced with the issue of protecting facts about current events news. To opponents of the news copyright bill, news seemed different, and they hoped that they could convince Congress it was.

News seemed different in several respects. First, current events did not seem to be a suitable subject for methodical, sustained study. Map and chart makers went on surveying expeditions using special tools to measure distances that would eventually be represented in their maps or charts. Authors of directories systematically canvassed neighborhoods or institutions. By contrast, events that formed the basis of the news could often not be predicted in advance, and thus it seemed fortuitous that a particular person would learn of a newsworthy event. As an article in February 21, 1884 issue of The Nation, commenting on the newspaper copyright bill, put it:

\footnotetext{
112 See, e.g., Galveston Daily News, February 17, 1884, p. 2. “[T]he smaller morning dailies . . are just able to take the state report of Associated Press matter and a few specials, are naturally somewhat badly affected when an afternoon pirate springs up beside them and takes nearly all they are able to give by an expenditure serious enough to them in their circumstances, and puts his subscription price lower than it could be if he paid part of the price for the telegrams. The pirate can sometimes run the local morning paper hard enough to keep it poor, and thus keep readers from obtaining as good a paper as they would otherwise have in their town.”

${ }^{113}$ Petition, The News Copyright Bill. (Copies of this form petition, as signed by representatives of many different newspapers, can be found in all of the folders cited above in note 102.) This language is echoed by The Evening Observer, Dunkirk, NY, the editor of which must have either read or wrote the petition: "What is news? The statement of facts, the history or current events. Can anyone create or invent a fact? Unquestionably not. What therefore are the reasonable grounds for a copyright?” The Evening Observer, Dunkirk, NY, April 3, 1884, p.2.,

${ }^{114}$ Newark Daily Advocate (Newark, OH), Mar. 3, 1884, p. 1.

115499 U.S. 340 (1991).
} 
[I]t is absurd to talk of a man who picks up a piece of news or an "item" as an "author" at all. The reason why copyright laws are passed is to secure the fruits of original, intellectual labor. But the proposed copyright in "news" does not do this. Any one may collect news without any original intellectual effort, and with very little effort of any kind. Some people do it by listening at keyholes, most people in the ordinary course of conversation with the persons whom they meet in the way of business or pleasure. If a collector of news in London telegraphs to New York that . . . Lord Cairns has offered Miss Fortescue £10,000 to release his son from his marriage engagement, who is the person whose "property" in the news ought to be protected, or who is the "author" of it? ${ }^{116}$

This view of how news was gathered - "in the ordinary course of conversation with the persons whom they meet in the way of business or pleasure" - was outdated even in 1884. Newspapers and news associations had already begun to employ reporters to go out and find news, not just to report whatever they happened to hear in casual conversations. And, of course, much of the investment was not in finding news, but in transmitting it quickly over great distances. Yet this image that news was acquired largely by chance was quite powerful, and fit in well with the argument that copyright required intellectual labor that was missing in newsgathering.

Second, fact-based works that were already protected under copyright law - maps, directories, calendars, road-books, and the like - were rarely in narrative form. Rather, they presented information in the form of lists, charts, maps, and the like. Not all news in newspapers was presented in narrative form; stock prices and weather reports weren't, for example. Both sides in the news copyright debate, however, assumed that much of what the bill would protect would be news stories - literary works in narrative form. This presented a new issue - how should copyright law deal with factual material presented in narrative form? For narrative literary works, copyright law already had developed a distinction between form and content. ${ }^{117}$ Thus, in Stowe v. Thomas, ${ }^{118}$ Justice Grier wrote: “A 'copy' of a book must, therefore, be a transcript of the language in which the conceptions of the author are clothed; of something printed and embodied in a tangible shape. The same conceptions clothed in another language cannot constitute the same composition, nor can it be called a transcript or 'copy' of the same 'book.",'119

Both opponents and proponents of the newspaper copyright bill seemed to proceed from the assumption that copyright in newspapers would only protect the literal language of a news

\footnotetext{
116 The Nation, Volume 38, n. 973 (February 21, 1884), p. 159.

117 Another way to illuminate this difference draws on Jane Ginsburg's distinction between "high authorship" and "low authorship" works. See Ginsburg, supra note 22, at 1866-1870. "High authorship" - the manifestation of a "personal authorial presence" - is much more easily accomplished or perceived in works of literary narration. Lists, maps and the like are much more likely to be associated with "low authorship." Of course, it is an illusion to think that lists of numbers and names are bereft of personal interpretation. As Justin Hughes has pointed out, there may be plenty of interpretation in numbers -- one person's notion of whether to divide a population count into Caucasians and Negroes, and how to count them, might be quite different from another's. See Justin Hughes, Created Facts and the Flawed Ontology of Copyright Law, 83 Notre Dame L. R. 43, 53-54 (2007).

11823 F. Cas. 201 (1853) (No. 13, 514).

${ }^{119} \mathrm{Id}$. at 207.
} 
story, and that any newspaper editor would be able to rewrite the story so that it recounted the same facts but avoided infringement liability. For the Atlanta Constitution, which opposed the newspaper copyright bill, this meant that the bill would be ineffectual: "Neither facts nor incidents can be copyrighted, but only the form in which they are presented. This is no remedy at all, for the papers that steal their news would not be balked by the copyright of form merely, and this is all that any copyright can cover."120 For the Galveston Daily News, which supported the bill, this meant that the bill would not give anyone a monopoly over news, but would stop newspapers from literal copying: "Copyright would protect a telegram or other matter in the form in which it appears. It would not prevent any writer from making in his own words a statement of the facts alleged in the telegram. The so-called newspapers that feed on other newspapers would either have to dismiss the scissors brigade and do some writing instead of clipping, or they would have to make arrangements with the Associated Press for its matter, if they wanted it within twenty-four hours."121

Interestingly, the Dunkirk (N.Y.) Evening Observer, a staunch opponent of the bill, made a rare direct mention of the existing copyright protection for directories, but it then distinguished news stories, without elaborating: "It is supposed by some that because . . . a city directory may be copyrighted, therefore news dispatches may be also; and so they may, so far as the original wording or form of dispatch is concerned, but the information contained in the dispatches cannot be, and any attempt to prevent the free use of such information will lead to litigation and result in failure."122

Third, news was important to the political and cultural life of the country, and to political and cultural speech, in a way that directories and maps weren't. As the Milwaukee Sentinel put it, "[news] becomes a matter of common information as soon as it is printed, and men may spread it by word of mouth or may write to one another about it . . . To prevent other journals from commenting upon it is to stifle free discussion, and to permit them to comment is to permit them to republish the matter."123 The concern about freedom of the press was particularly pointed in light of the size and power of the Associated Press - many were sure that the practical result of the news copyright bill would be, not the decentralized sale and purchase of news stories by many newspapers, but further concentration of the news business. As The Evening Observer (Dunkirk, NY) put it, “The Sherman copyright bill [is] designed to create a monopoly of newsgathering. It was instigated and was backed by the associated press and the metropolitan newspapers. The associated press is the worst kind of a monopoly, and yet additional protection

\footnotetext{
120 The Atlanta Constitution, March 20, 1884, p. 4. Five days later, the Constitution quoted from a lecture by James Whitney, a New York attorney, to the same effect: “[I]t is only the "writings" of an author which congress is authorized by the constitution to protect. There can be no copyright on news alone, the copyright must be on the verbal form. . . [I]t would be ... easy to abridge or put the ideas or information in totally different and original language, and this would constitute a new and distinct writing, independent of the other, and which the other could not reach.” The Atlanta Constitution, March 25, 1884, p. 4.

${ }^{121}$ Galveston Daily News, February 17, 1884, p. 2.

122 Dunkirk (N.Y.) Evening Observer, p. 4.

123 Milwaukee Sentinel, February 22, 1884, p. 4. Of course, one might use the doctrine of fair use to allow commentary on a copyrighted news article, but that would be unlikely to comfort the writer in the Sentinel: the noncategorical, case-specific nature of fair use doctrine would make it difficult for newspapers to know in advance which uses would be protected and which wouldn't, and could lead them to shy away from any use that could conceivably generate litigation.
} 
is asked for! . . . We cannot understand how a monopoly of newsgathering can in any way advantage the people."124 The Associated Press was supposed to be neutral, but Menaham Blondheim has argued that its selection of news items was actually biased in favor of the Republican Party and against the Democrats, ${ }^{125}$ and it was also not above agreeing to refrain from any criticism of the Western Union Telegraph Company, in return for favorable access to telegraph lines and a promise that Western Union would not itself enter the news business. ${ }^{126}$

Fourth, with works such as directories and maps, application of a "market substitute" doctrine of infringement could accommodate the most pressing concerns about free speech while protecting the core economic interests of copyright owners. Directories and maps documented large numbers of names, addresses, geographical relationships, and the like, and were bought as reference works. Purchasers would consult them many times over an extended period, and would likely consult different parts of the works at different times. That market for reference works was only endangered if a copier reproduced all or a substantial portion of a work. Thus, in the market for reference works a "market substitute" doctrine would leave room for the kind of copying that authors who did not set out to duplicate the work in question were likely to want to do. An author would be free to use and incorporate a single directory entry or some information incorporated on a map without fear of infringement.

Newspapers were different, however. Each daily edition was modest in size, and its market value was short-lived. People often bought the daily paper to read the lead story about some sensational event, and then discarded it. Subsequent authors might well want to repeat the essential facts of that lead story. Under these circumstances, the "market substitute" doctrine had much less maneuvering room to mediate between the economic interests of the copyright owner and the interests of the reader in speaking freely about what he or she had learned. The situation was even worse with news tickers, which dispensed content in a continuous stream, making it difficult to identify a "work" of any size greater than a single news item.

In light of these conditions, the logic that lay behind the intellectual-labor view of originality, and the consequent protection of fact-based works, probably seemed quaint to the opponents of the news copyright bill, and the "market substitute" infringement doctrine did not seem to offer any clear relief. Were the events that formed the basis of news reports "common sources of information open to all"? Once one heard of the report of an event, it was too late to go witness it oneself - time had moved forward - and those who did witness it were already dispersing. Moreover, the means of transmitting the report from the distant site of the event to one's own location were not open on equal terms to all: the Western Union owned the telegraph lines, and it offered the Associated Press special terms. Thus, maps, directories, and news reports might be equated at some abstract level, but they did not seem similar when placed in their concrete social context.

In the end, the news copyright bill died. The New York Times had predicted that the political influence of the country press, widespread throughout the Union, could decide the issue:

\footnotetext{
124 The Evening Observer (Dunkirk, NY), April 1, 1884, p.2.

125 See Menahem Blondheim, News Over the Wires: The Telegraph and the Flow of Public Information in America, 1844-1897, pp. 175-187 (1994).

${ }^{126}$ See id. at 151.
} 
"If country members of Congress are instructed by their constituents that the news copyright bill is a defense for metropolitan journals, (as is very likely the case,) the country members will defeat the bill beyond peradventure."127 The "country members" never got to vote on the bill; it was reported out of the Committee of the Library with a recommendation that it not pass, and was allowed to disappear quietly. ${ }^{128}$

B. Seeking Protection for News in the Courts. By the late spring of 1884, the Associated Press realized that its quest to obtain legislative protection for news was going to be futile. From the vantage point of 1919, Henry Watterson looked back on his trip to Washington to lobby for the bill as a "fool's errand."129 But the legislature wasn't the only forum in which the Associate Press could pursue protection for news. Watterson recounted that while he was in Washington, "a learned but dissolute lawyer said to me, "You need no act of Congress to protect your news service. There are at least two, and I think four or five, English rulings that cover the case. Let me show them to you.","130 Watterson then commented, "To a recent date the Associated Press has relied on these decisions under the common law of England."131

Watterson no doubt received this advice before he testified in front of the House Committee on the Judiciary on March 24, 1884, because his testimony on that occasion featured the argument that English courts had already decided in favor of copyright for news. ${ }^{132}$ Watterson relied principally on Vice Chancellor Sir Richard Malins's ${ }^{133}$ opinion in the 1869 English Court of Chancery case of Cox v. Land and Water Journal Company. ${ }^{134}$ Cox was in more than one respect a great case for Watterson and the interests that he represented. Mr. Cox, the plaintiff, was the proprietor of a newspaper called the Field. The Field had published a directory of hunts in the United Kingdom which included "the name of each hunt, with the nearest town convenient for strangers, the number of the hounds in the pack, the hunting days, the names of the masters, huntsmen, and whips, and the address of the kennel."135 The defendant had copied that list from the Field and published it in another periodical, the Land and Water Journal. The court held for the plaintiff, finding that he had a right to the material that he had invested in collecting. Of course, a directory of hunts is not a news story. However, the Cox court posed a hypothetical that did involve news, and that involved a scenario that was particularly relevant to telegraph news services like Watterson's Associated Press:

Now, suppose, for instance, the proprietor of a newspaper employs a correspondent abroad, and that correspondent, being employed and sent abroad at great expense, makes

\footnotetext{
${ }^{127}$ The New York Times, Feb. 18, 1884, p. 4.

${ }^{128}$ See 15 Cong. Rec. 3077 (April 18, 1884).

${ }^{129}$ Henry Watterson, Marse Henry: An Autobiography, vol. II, p. 104 (1919) [available on Google Books http://books.google.com/books?id=ZSKbwauEbnIC\&pg=PR3\&dq=marse+henry+volume+II] .

${ }^{130} \mathrm{Id}$. at 105.

${ }^{131} \mathrm{Id}$.

${ }^{132}$ See The Evening Observer (Dunkirk, NY), March 29, 1884, p.1. Indeed, Watterson's visit with the "learned but dissolute old lawyer" can probably be more precisely placed between March $14^{\text {th }}$ and March $24^{\text {th }}$, because The Evening Observer's account of Watterson's testimony on the $24^{\text {th }}$ notes that it was "substantially identical with his testimony before the joint Library Committee on the $14^{\text {th }}$ inst., except that he submitted the following comprehensive statement of principles adjudicated in cases on the subject.” Id.

${ }^{133}$ Vice Chancellor Malins's obituary can be found in James Dodsley, The Annual Register 1882, p. 111 [available on Google Books at http://books.google.com/books?id=sXVdAAAAIAAJ]

134 [L R] 9 Eq 324 (1869).

${ }^{135} \mathrm{Id}$.
} 
communications to a newspaper which are highly appreciated by the public, can it be said that another newspaper, published, perhaps, in the evening of the same day, may take and publish those communications in extenso, with or without acknowledgment? ${ }^{136}$

It was clear that the question was rhetorical, and the answer was supposed to be "no"; that was exactly the answer the news agencies wanted.

The major contemporary treatises also presented the law on copyright in news in terms that were favorable to news agencies. In the 1881 Second Edition of his already well-established English treatise, Walter Copinger stated that "there can of course by copyright in telegrams,"137 and cited in support of this statement a recent Australian case, Wilson v. Luke. ${ }^{138}$ According to Copinger, "[i]t was argued for the defendant [in Wilson] that, as the telegrams were matters of news, any one could re-publish them without breach of the Copyright Act; but Mr. Justice Molesworth held that the plaintiff had a property in the telegrams, and that no one could republish them without the permission of the person to whom they had been sent in the first instance."139

An 1891 treatise, Fisher and Strahan's The Law of the Press, ${ }^{140}$ framed the issue with exquisite clarity, and also decided it in favor of news agencies. "No doubt there is copyright in the literary form given to news," 141 wrote Fisher and Strahan. "The difficulty is whether there is copyright in the substance of the news." 142 They considered that issue at some length, and concluded that "on the principle that applies to the cases of Directories and Lists of judgments, we are inclined to believe that there is." 143

It is difficult to see what distinction can be made between the skill and labour necessary to collect the news of a district and the skill and labour necessary to collect the names and residences of the inhabitants of a district, or to compile a list of the judgments recovered in a district. In all three cases the material on which the result is based is common to the world, and two persons working accurately on that material would produce practically the same result, and the result would be a statement of facts. ${ }^{144}$

In support of their conclusion, Fisher and Strahan cited both Cox and Wilson, the cases mentioned earlier by Watterson and Copinger.

In spite of those cases and commentary, however, the news agencies still faced a problem under U.S. copyright law. The Field, the newspaper at issue in Cox v. Land and Water Journal Company, had not been registered, but relying on a somewhat doubtful interpretation of English law, Vice Chancellor Malins granted relief to the plaintiff anyway. ${ }^{145}$ In 1881 , that interpretation

\footnotetext{
${ }^{136} \mathrm{Id}$.

${ }^{137}$ Walter Arthur Copinger, The Law of Copyright in Works of Literature and Art 100-101 (2 ${ }^{\text {nd }}$ ed. 1881).

${ }^{138}$ Copinger discusses the case at length without actually citing it, but it is Wilson v. Luke, 1 Vict. L. R. Eq. 127 (1875).

${ }^{139}$ Id. at 101 .

140 Joseph R. Fisher \& James Andrew Strahan, The Law of the Press (1891).

${ }^{141} I d$, at 32 .

142 Id. at 33 .

${ }^{143} \mathrm{Id}$.

${ }^{144} \mathrm{Id}$.

${ }^{145}$ Malins concluded that, because newspapers were not explicitly mentioned in the sections of the Act that concerned registration, they were not subject to a registration requirement. This construction, however, raised the issue whether newspapers were protected by the Copyright Act at all. Malins left this issue undecided, stating that if
} 
was pointedly questioned in Walter $v$. Howe, ${ }^{146}$ which held that newspapers did need to be registered to be protected under English copyright law. The holding in Walter was later followed by two 1889 cases, which confirmed that there would be no protection of newspapers without registration. ${ }^{147}$ In England, however, there was a special registration provision for periodicals, which allowed the owner of copyright in the periodical to register just once for the entire series; that registration was good so long as the periodical maintained regular publication. ${ }^{148}$

The U.S. Copyright Act did not contain any special registration provision for works published in series. It continued to require registration for each separately published work covered under the Act. Daily newspapers continued not to register their individual issues as they were published; and if under certain circumstances telegraph dispatches themselves were going to count as publications, they would face even greater difficulties meeting the registration requirement. Thus, news agencies needed a legal strategy for avoiding the registration requirement under U.S. copyright law.

This issue came to a head in 1901, when Western Union sued a company called the National Telegraph News Company. Western Union had itself entered the news business, in a limited fashion. It had purchased the Gold \& Stock Telegraph Company, which owned the rights to an early telegraph ticker machine, and had continued the Gold \& Stock business of providing

the owner of a newspaper acquired for publication an article or other material from an author, "he acquires - I will not say as copyright, but as property - such a property in every article for which he pays, under the 18th section of the Act, or by the general rules of property, as will entitle him, if he thinks it worth while, to prohibit any other person from publishing the same thing in any other newspaper, or in any other form." Cox v. Land and Water Journal Co., [L R] 9 Eq 324 (1869) (emphasis added). As the italicized portion of the quote indicates, Malins somewhat dubiously avoided deciding whether he was awarding relief to the newspaper based on statutory copyright, common law copyright, or some other common law doctrine, and did not face the issue whether the first of those might preempt the latter two.

146 (1881) 17 Ch. D. 708 (Eng.).

147 See Trade Auxiliary Co. v. Middlesborough \& Dist. Tradesmen’s Prot. Ass’n, (1889) 40 Ch. D. 425, 434 (Eng.)(Cotton, J.); Cate v. Devon \& Exeter Constitutional Newspaper Co., (1889) 40 Ch. D. 500 (Eng.)(North, J.). For an excellent discussion of this sequence of cases, see Lionel Bently, Copyright and the Victorian Internet: Telegraphic Property Laws in Colonial Australia, 38 Loy. L.A. L. Rev. 71, 91-92 (2004).

${ }^{148}$ Section 19 of the Copyright Act provided that the proprietor of copyright in "any encyclopedia, review, magazine, periodical work, or other work published in a series of books or parts," could register the entire series prospectively, so long as it maintained regular publication. Act 5 \& 6 Vict. c. 45, sec. 19, quoted in Cox v. Land and Water Journal Co,, [L R] 9 Eq 324 (1869).

Some Australian states also had such a provision, which meant that the Argus, a Melbourne newspaper, could sue the Gipps Land Mercury under the Victoria copyright act for publishing reports, and alterations of reports, that the Argus had received by telegraph, and for which it had paid a large sum of money. The Argus prevailed, but the opinion as reported is quite equivocal about whether copyright protects factual matter or not. On the one hand, Mr. Justice Molesworth states that "[t]he right of copyright extends not merely to the special produce of a writer's mind, but to the results of his inquiries as to facts, which anybody taking the trouble to learn may, which he reduces to order, as in the case of directories, \&c.” Wilson v. Luke, 1 Vict. L. R. (Eq.) 127, 140 (1875). On the other hand, Justice Molesworth states that he will not issue an order that "extends to publishing the intelligence, not merely copying the telegram." Id. at 141. Nevertheless, the injunction extends to "any copy or colorable alteration, or adaptation in the nature of copies of any telegrams from England received and published by the plaintiffs.” Id. It is difficult to know how one could publish the "intelligence" contained in a telegram without running afoul of the injunction. Two commentators ended up citing Wilson v. Luke for the proposition that there could be copyright protection for news. See Walter Arthur Copinger, The Law of Copyright in Literature and Art101 ( ${ }^{\text {nd }}$ ed. 1881); Joseph R. Fisher \& James Andrew Strahan, The Law of the Press 33 (1891). Another commentator, writing a decade later, maintained it did not protect copyright in news, but only held that "the smallest taking of a selection or arrangement of news will be prohibited.” E.J. MacGillivray, A Treatise Upon the Law of Copyright 104 (1902). 
news service directly to ticker machines. Those tickers were installed in hotels, saloons, and private companies that wanted "instant information of passing events of more or less importance throughout the world," and sometimes, in particular, news of sporting events, no doubt of special interest to gamblers and bookmakers. ${ }^{149}$ The National Telegraph News Company had a competing business of providing a news service through tickers. It admitted that it had been copying news items from the Western Union tickers, and sending them out on its own wires, "so that within a very few minutes from the time th[e] news appears upon the tapes of the [Western Union] tickers it re-appears upon the tapes of the [National Telegraph News Company] tickers."150 Western Union argued that the National Telegraph News Company charged less for its subscriptions because it had no expenses for gathering news, and that Western Union had been forced to lower its prices to retain subscribers. ${ }^{151}$

Western Union obtained a preliminary injunction from the District Court that prohibited National Telegraph News from using any news items it had gathered from Western Union tickers for 60 minutes after they appeared on those tickers. National Telegraph News appealed. National's chief argument on appeal was that Western Union had published the ticker tapes without registration, notice, or deposit, and had therefore abandoned common-law copyright in them without acquiring copyright under federal law. ${ }^{152}$ Western Union decided to argue that the reports that it transmitted to the tickers were not copyrightable subject matter under federal law, and hence that federal requirements of registration, notice and deposit upon publication did not apply:

[W]e respectfully protest at the outset, and in the holy name of arts and letters, that the reports of passing events sent over [Western Union] tickers to saloons, hotels and brokers' offices, is not, properly speaking, literature; that it does not come within the purview of the copyright statutes; that would not be entitled to the protection of such statutes even if every condition precedent prescribed by them had been punctiliously complied with; and that it would not, therefore, be subject to diminution because of any failure to comply therewith. ${ }^{153}$

Why were the reports not copyrightable subject matter? Western Union cited the old 1829 case of Clayton v. Stone, ${ }^{154}$ and argued as Justice Thompson had in Clayton that the ticker reports provided only "a history of inconsequential contemporaneous events which adds nothing to the learning of the world.” ${ }^{155}$ However, perhaps aware that Clayton had not remained a strong precedent, it also argued that news was not copyrightable because it was not the product of any author: "Could you call the writer of [a telegraph message giving the result of a baseball match or a horse-race, or the fluctuations of the stock market] an 'author?' The very absurdity of the proposition is its own refutation."156 Thus, a prominent force in the news industry, Western Union, had itself decided to adopt a creativity-based view of originality to avoid a charge of

\footnotetext{
149 Brief for Appellee at 2, National Telegraph News Co. v. Western Union Telegraph Co., No. 789 (7 ${ }^{\text {th }}$ Cir. 1901$)$.

150 Id. at 3.

151 Id. at 4.

152 See Brief for Appellant at 8-34, National Telegraph News Co. v. Western Union Telegraph Co., No. 789 (7 $7^{\text {th }}$ Cir. 1901). National also argued that Western Union was a common carrier and was thus obligated to offer it a ticker subscription on terms equal to those of other subscribers. See id. at 34-43.

153 Brief for Appellee at 8, National Telegraph News Co. v. Western Union Telegraph Co., No. 789 (7 $7^{\text {th }}$ Cir. 1901$)$.

1545 F. Cas. 999 (C.C.S.D.N.Y. 1829) (No. 2872).

155 Id. at 10 .

${ }^{156}$ Id. at 9.
} 
abandonment and forfeiture of copyright protection, and to try its luck arguing that common law still protected its reports.

The Seventh Circuit affirmed the preliminary injunction, and Judge Peter Grosscup wrote an opinion that provides a pioneering, astoundingly clear use of the rhetoric of creativity-based originality, and of the associated notion of the romantic author. "Authorship," he wrote, "implies that there has been put into the production something meritorious from the author's own mind; that the product embodies the thought of the author, as well as the thought of others; and would not have found existence in the form presented, but for the distinctive individuality of mind from which it sprang." 157 News reports, he concluded, did not usually bear the stamp of a particular mind, and therefore were not the products of an author that copyright law should protect.

A mere annal ... is the reduction to copy of an event that others, in a like situation, would have observed; and its statement in the substantial form that people generally would have adopted. . . . [I]f . . writings are a mere notation of the figures at which stocks or cereals have been sold, or of the result of a horse race, or base-ball game, they cannot be said to bear the impress of individuality, and fail, therefore, to rise to the plane of authorship. In authorship, the product has some likeness to the mind underneath it; in a work of mere notation, the mind is guide only to the fingers that make the notation. One is the product of originality; the other the product of opportunity. ${ }^{158}$

Nevertheless, Grosscup and his brethren held, the news service provided by Western Union has a commercial and social value that deserves legal protection - it is a "modern enterprise - one of the distinctive achievements of our day - which, combining the genius and accumulations of men, with the forces of electricity, combs the earth's surface, each day, for what the day has brought forth, that whatever befalls the sons of men shall come, almost instantaneously, into the consciousness of mankind." 159 Thus, the court upheld the injunction on common-law grounds. The release of National Telegraph News decision marks a significant moment in American copyright history. For the first time, a federal court concluded that a large category of products of intellectual labor - news accounts that were "mere annals" - was not copyrightable subject matter, on the basis of a creativity-based interpretation of the originality requirement.

\section{Parallels and Effects: The Context and Aftermath of the Newspaper Copyright} Bill Debate and the National Telegraph News Decision. The debate over the Newspaper Copyright Bill and the National Telegraph News litigation were not the only fora in which copyright law was faced with the increasing desire of newspapers for protection of their investments in newsgathering. English jurists had to deal with the same trend, and Walter Copinger's treatise on copyright law, of which new editions were regularly being published during the era - 1870, 1881, 1893, 1904, and 1915 - provides an interesting glimpse of developments. The First and Second Editions of Copinger's treatise, published in 1870 and 1881, do not reject copyright in news; if anything, the Second Edition, as noted above, tends toward supporting it. ${ }^{160}$ In 1893, however, the Third Edition makes a break. Copinger states: "There can be little doubt but that there is copyright in the literary form given to news - not in

\footnotetext{
${ }^{157}$ National Tel. News Co. v. Western Union Tel. Co., 119 F. 294, 297-98 (7 $7^{\text {th }}$ Cir. 1902).

${ }^{158}$ Id. at 298.

${ }^{159} \mathrm{Id}$. at 300 .

${ }^{160}$ See supra notes 136-38 and accompanying text.
} 
the substance of the news itself, but in the form in which it is conveyed. . . . One newspaper cannot legally use the telegrams sent to another, but we are not able to go so far as to admit copyright in the substance of the news as distinguished from the form of language by which that substance is conveyed." 161 Interestingly enough, however, he cites no authority for this position the statement appears to be no more than Copinger's own opinion.

The 1904 Fourth Edition of Copinger's treatise, written by J.M. Easton, retained the Third Edition passage quoted above, but Easton added a citation to the 1892 decision of the Court of Chancery in Walter v. Steinkopff. ${ }^{162}$ In Walter, the St. James Gazette had copied several items from the Times, most prominently excerpts of a piece by Rudyard Kipling on America. When the Times sued, the Gazette set up as one defense an established custom of borrowing between newspapers, which it described in some detail. No doubt this custom had in fact existed in England, just as it had in the United States. Yet Sir Frederick North, who decided the case, held that such a custom had no legal effect. Then came the passage that supported the statement in Copinger's treatise: "It is said that there is no copyright in news. But there is or may be copyright in the particular forms of language or modes of expression by which information is conveyed ...."163 And, decided North, the Gazette had copied those forms of language from the Times. Notably, North presents the statement that there is no copyright in news in the passive case, without citations, and hence without any attribution. It sounds as though North may be stating a universally recognized truth, and yet, along with Copinger's contemporaneous Third Edition statement, similarly floated without authority, it is among the first articulations of the principle that there can be no copyright in news, and the nascent fact/expression doctrine.

Back in the United States, both the debate on the Newspaper Copyright Bill and the National Telegraph News decision influenced commentators and courts. In his 1912 book Copyright: Its History and Its Law, Richard Rogers Bowker contended that the failure to pass the Newspaper Copyright Bill meant that there was no copyright protection for news, but only for the literary form in which it was recounted:

A bill to protect news for twenty-four hours was at one time before Congress, but was never passed. There is, therefore, no copyright protection for news as such, but the general copyright of the newspaper or a special copyright may protect the form of a dispatch, letter or article containing news. ${ }^{164}$

Bowker then noted that the National Telegraph News case provided common-law protection for news on ticker tapes. ${ }^{165}$ The following year, the Southern District of New York cited the Bowker account with approval in support of a broad statement that facts were not copyrightable: "[T]here can be no piracy of facts, because facts are public property,"166 stated Judge Hough; he then opined that "a fair summary of the law on [the impossibility of copyrighting news] is, I think, contained in Bowker on Copyright, pp. 88, 89."167 The case proceeded to hold that fiction presented as news should also be uncopyrightable, essentially adopting a theory of estoppel.

\footnotetext{
${ }^{161}$ Walter Arthur Copinger, The Law of Copyright in Works of Literature and Art (3rd Ed. 1893).

1623 Ch. 489 (1892). Thus, Walter v. Steinkopff was actually decided before the Third Edition of the Copinger treatise was published, but likely after the Third Edition manuscript was complete. 
In his 1917 copyright law treatise, ${ }^{168}$ Arthur William Weil quoted extensive passages from National Telegraph News, which he praised as "an extremely able opinion." 169 In particular, Weil quoted approvingly the passage from National Telegraph News denying copyright to "mere annals" while criticizing Justice Holmes's apparent acceptance of the copyrightability of directories in Bleistein v. Donaldson Lithographing Co. ${ }^{170}$ In the same year, William B. Hale, whose copyright treatise was published as volume 13 of Corpus Juris, ${ }^{171}$ cited National Telegraph News in support of two related propositions: that there is no copyright in news, ${ }^{172}$ but that there is common-law protection of news, which is not destroyed by publication because news is not literary property. ${ }^{173}$

1917 is also the year that Judge Augustus Hand issued the District Court decision in Associated Press v. International News Service. ${ }^{174}$ This litigation, of course, culminated in the Supreme Court's decision in International News Service v. Associated Press ${ }^{175}$ the following year. The Supreme Court's recognition of a property right in news in this litigation has been widely recognized and extensively analyzed. The role of the INS case in establishing that news is not copyrightable, however, has received somewhat less emphasis. Judge Hand's opinion decision directly addressed the policy question - should news be given some post-publication protection? - with little discussion of the legal issue of how to avoid dedication to the public under the federal copyright scheme, which by that time had dropped the registration requirement, but still required proper notice upon publication. ${ }^{176}$

As for the issue of post-publication protection for news, Hand announced that he was "personally satisfied ... that the right exists to prevent the sale by a competing news agency of news which is taken from early publications of complainant's members before sufficient time has elapsed to afford opportunity for general publication." ${ }^{177}$ In support of such a proposition, Hand rested heavily on National Telegraph News, and his opinion contained a three-paragraph, 700 -word quote from Judge Grosscup’s opinion in that case. ${ }^{178}$ Yet Judge Hand concluded that the legal issue was not sufficiently free from doubt to grant a preliminary injunction prohibiting copying altogether. Rather, he issued a preliminary injunction that only forbade INS from inducing agents of the Associated Press, or of its member newspapers, to furnish it with news in breach of AP policy. That meant that INS was still free to obtain published copies of East Coast newspapers and transmit that news to West Coast clients.

Both sides appealed the preliminary injunction. As appellate counsel, the Associated Press engaged none other than Peter Stenger Grosscup himself, author of the National Telegraph

\footnotetext{
${ }^{168}$ Arthur William Weil, American Copyright Law (1917).

${ }^{169} \mathrm{Id}$. at 35; for the quoted passages, see id. at 36, 42-43.

${ }^{170}$ See id. at 43 (criticizing Bleistein v. Donaldson Lithographing Co., 188 U.S. 239 (1903)).

${ }^{171}$ William B. Hale, A Treatise on the Law of Copyright and Literary Property, published as volume 13 of William Mack \& William B. Hale, Corpus Juris (1917).

${ }^{172}$ Id. at 1109,1109 n.93

${ }^{173}$ Id. at 956, 956 n. 34 (containing a 500-word quotation from the National Telegraph News decision).

174240 F. 983 (S.D.N.Y. 1917).

175248 U.S. 215 (1918).

176 The National Telegraph News case was litigated before 1909, when federal copyright law still required registration before publication. The 1909 Act removed the registration requirement, so that the principal requirement for obtaining federal copyright protection became publication with proper copyright notice.

${ }_{177}$ Associated Press v. International News Service, 240 F. at 996.

${ }^{178}$ See id. at 993-94.
} 
News opinion, who had resigned from his Seventh Circuit judgeship in $1911 .{ }^{179}$ In a split decision, the Second Circuit, citing National Telegraph News with approval, ${ }^{180}$ extended the preliminary injunction to cover copying of Associated Press news even when it was procured from publicly available newspapers. Judge Charles Merrill Hough's opinion directly addressed the issue of whether news content was copyrightable, and embraced a creativity-based view of originality: "It may be granted that ... publication at common law terminated an author's rights in his manuscript and the fruits of his brain; yet it still remains true that plaintiff's property in news is not literary at all, that it is not capable of copyright, and that 'publication,' as that word is used in the long line of decisions regarding literary rights, has no determinative bearing on this case."181

When the case reached the Supreme Court, it split the Justices six to three, but not on the issue whether copyright law incorporated a creativity-based originality requirement. For the majority, Justice Pitney concluded that "the news element - the information respecting current events contained in the literary production - is not the creation of the writer," was not copyrightable. Justice Pitney echoed concerns expressed in both the Newspaper Copyright Bill debates and the National Telegraph News decision about granting exclusive rights over "the history of the day."183 The framers of the Constitution, he argued, could not have "intended to confer upon one who might happen to be the first to report a historic event the exclusive right for any period to spread the knowledge of it." ${ }^{\text {184 }}$ In dissent, Justice Brandeis expressed similar support for a creativity-based originality standard that would exclude factual matter. "[I]ntellectual productions, he contended, "are entitled to such protection only if there is underneath something evincing the mind of a creator or originator, however modest the requirement. The mere record of isolated happenings . . . are denied such protection." ${ }^{185}$ In support, he cited, among other cases, National Telegraph News. ${ }^{186}$ Justice Holmes's separate dissent did not touch directly on the issue, but he could be safely counted on the side of creativity-based originality as well, since his statement in the 1903 case of Bleistein $v$. Donaldson Lithographing Co. ${ }^{187}$ is a crystalline expression of that view: "The copy is the personal reaction of an individual upon nature. . . a very modest grade of art has in it something irreducible, which is one man's alone. That something he may copyright . . .."188

\footnotetext{
${ }^{179}$ See Associated Press v. International News Service, 245 F. 244, 247 (2d Cir. 1917) (listing Peter S. Grosscup as lead counsel for plaintiffs); Federal Judicial Center, Biographical Directory of Federal Judges, http://www.fjc.gov/public/home.nsf/hisj (entry for “Grosscup, Peter Stenger” notes that he resigned on October 23, 1911).

${ }^{180}$ See Associated Press v. International News Service, 245 F. 244, 249 (2d Cir. 1917).

${ }^{181}$ Id. at 250.

${ }^{182}$ International News Service v. Associated Press, 248 U.S. 215, 234 (1918).

${ }^{183} \mathrm{Id}$.

${ }^{184}$ Id. Of course, Pitney's remark can be criticized as a "straw man” overstatement. No one has ever contended that copyright law would grant someone exclusive rights over news because he was the first to report it. Even under a broad view of copyright protection, anyone would still be free to report the news if he had a source for it that was independent of the first reporter. Even with that correction, however, Pitney can still be seen as expressing the concern that a person or organization would be able to monopolize a news story when there was no independent source, and that there were likely to be many cases in which no independent source could be found.

${ }^{185} \mathrm{Id}$. at 254 (Brandeis, J., dissenting).

${ }^{186} \mathrm{Id}$. at 254 ก. 6.

187188 U.S. 239 (1903).

${ }^{188} \mathrm{Id}$. at 250.
} 
As an experiment in common-law protection of intellectual property, International News Service v. Associated Press can probably be counted as a failure. It has not spawned a broad jurisprudence of common-law intellectual property, but has been given a narrow reading, limited to "hot news" misappropriation; ${ }^{189}$ and its views on federal court jurisdiction have been thoroughly repudiated. ${ }^{190}$ As the statement of a view of originality that excludes independently created factual accounts from copyright protection, however, it can be counted as a success. Although some post-INS courts continued to protect compilations of facts without a showing of creative selection or arrangement, the Supreme Court eventually vindicated INS in Feist Publications, Inc. v. Rural Telephone Service Co, Inc. ${ }^{191}$ Thus, the debate over copyright in news, beginning with the Newspaper Copyright Bill in 1884 and continuing through the National Telegraph News case, resulted in the rise of a creativity-based model of originality that received unanimous Supreme Court approval in 1918 and has only been strengthened and broadened by Feist.

\section{Lessons from the Newspaper Copyright Debate}

What can we learn from the debate over copyright in news, and the transformation of originality doctrine in that debate?

First, it is a reminder that although copyright doctrines and rationales may be framed at high levels of abstraction, they are likely to enjoy success only under a much more particular set of conditions, and those conditions are likely to change over time. Nineteenth-century judges and commentators articulated a view of copyright originality under which factual matter was entitled to copyright protection; those who wanted to sell works that imparted information were exhorted to go out and gather it themselves, rather than free-ride on the intellectual labor of those who had already gathered it. Yet while that view is stated in general enough terms to make it applicable to news and news-gathering, the view became settled orthodoxy without ever being tested within the news industry, because at that time the news industry had no interest in protection for news. Once it gained such an interest, the intellectual labor theory was severely strained, because news, as it functioned within late-nineteenth-century American culture, did not fit the presuppositions of that theory very well. Witnessing a current event seemed to many to be as much a matter of chance as of labor and investment. News often came in narrative form, which allowed for a greater distinction between form and content than was possible with directories and maps. News seemed to be of more immediate political and cultural importance, and its free dissemination seemed particularly important when non-local news gathering was dominated by a very small number of large organizations. Moreover, "market substitute" infringement doctrine had much less maneuvering space to mediate between the economic interests of copyright owners and the interest in free dissemination when individual news items could become the selling points for newspaper issues, and could become independent works in the continuous stream of the news ticker.

\footnotetext{
189 See, e.g., National Basketball Ass'n v. Motorola, 105 F.3d 841 (2d Cir. 1997).

190 See, e.g., McKevitt v. Pallasch, 339 F.3d 530 ( $7^{\text {th }}$ Cir. 1993) (INS v. AP "no longer is legally authoritative because it was based on the federal courts' subsequently abandoned authority to formulate common law principles in suits arising under state law though litigated in federal court.”).

191499 U.S. 340 (1991). But see Jane C. Ginsburg, No "Sweat”? Copyright and Other Protection of Works of Information After Feist v. Rural Telephone, 92 Colum. L. Rev. 338, 352 (1992) ("Nonetheless, judicial inclination to reprimand sweat theft remains strong.").
} 
Second, the news copyright debate demonstrates the interdependence of the myriad doctrines that constitute copyright law. It is not particularly surprising that the "country press," which was opposed to any form of protection for news, advanced a creativity-based view of the originality requirement under which news matter was not copyrightable. Yet under copyright law as it existed at the turn of the twentieth century, the Western Union, which strongly desired protection for its news items, decided that it also wanted to advance a creativity-based view of originality, because its news ticker service could not satisfy the formalities of registration and notice; better to argue that news was outside of the reach of copyright altogether, and could therefore still qualify for common-law protection.

The removal of news content from copyright - a contraction of copyright protection along the dimension of copyrightable subject matter - may also have made it easier for copyright to expand along other dimensions. If copyright was going to focus less on news, and more on fiction and entertainment, then the opposition to increases in scope of protection, such as protection of derivative works, and in length of copyright term, would decrease. This continues to be relevant to the current debate about whether patent and copyright law should have special rules for each industry that avails itself of patent or copyright protection. ${ }^{192}$ It remains to be seen whether tailoring is a useful tool to ensure that each industry receives protection at a level that is optimal for society as a whole, or is an opportunity for each industry to ensure that as much market surplus as possible is captured by producers rather than consumers.

One important issue that cannot be completely resolved within the scope of this article is the fate of the distinction between news reports, on the one hand, and other fact-based works like directories and maps, on the other. If, indeed, news reports posed different issues than directories and maps, thus requiring a rethinking of prevailing originality doctrine, why doesn't copyright law continue to distinguish between them? Why did the Feist Court end up treating them all the same, with a broad, sweeping statement about the non-copyrightability of facts? There is certainly more work to be done on this issue, but perhaps the reader will indulge a few preliminary observations. First, the distinction persisted for decades, albeit somewhat inconsistently given the number of federal courts involved and the confusion in the law. Important lower courts, such as the Second Circuit, gave notice that in spite of INS $v$. AP they were sticking to the view that the copyright in directories was not limited to creative selection and arrangement. ${ }^{193}$ Second, the argument against copyright in news that had the most immediate and simplest intuitive appeal - that reporters did not create the facts that they documented - had implications beyond news, and those implications were difficult to ignore. Third, the Copyright Act did not provide a strong textual hook for maintaining such a distinction. Interestingly, the Berne Convention, the drafting of which began in 1884 - the same year as the Newspaper Copyright Bill - contemplated that its signatories would treat news differently. It provided for a default rule of free copying of news stories, another sign that the custom of news copying was not confined to the United States. ${ }^{194}$ Yet if the United States never adopted special

\footnotetext{
192 See, e.g., Michael W. Carroll, One for All: The Problem of Uniformity Cost in Intellectual Property Law, 55 Am. Univ. L. Rev. 845 (2006); Dan L. Burk \& Mark A. Lemley, Is Patent Law Technology Specific?, 17 Berkeley Tech. L. J. 1155, 1159 (2002); Glynn S. Lunney, Jr., Patent Law, the Federal Circuit, and the Supreme Court: A Quiet Revolution, 11 Sup. Ct. Econ. Rev. 1 (2004).

193 See, e.g., Jeweler's Circular Pub. Co. v. Keystone Pub. Co., 281 F. 83 (2d Cir. 1922).

${ }^{194}$ Article 7 of the original Berne Convention of September 9, 1886 provided that newspaper and magazine articles published in any country that was a member of the Berne Union could be reproduced, in the original language or in translation, unless the authors or editors expressly prohibited it; furthermore, the prohibition would not apply to
} 
statutory protection for news stories, it never adopted a special exclusion for them either, and that made it difficult to maintain a distinction.

Thus, all that remains is to reiterate the main thesis of this article. An intellectual-laborbased view of originality, and of the scope of copyright protection, developed during an era when the news industry was uninterested in copyright. When major news industry players became interested in protection for news, due to technological and social changes that reshaped that industry, debate about the appropriateness and shape of that protection in Congress and the courts gave a substantial boost to a creativity-based view of originality that grew in dominance during the $20^{\text {th }}$ century and today is established orthodoxy.

articles that discussed political matters or news of the day. It was not until the Stockholm Conference in 1967 that this default blanket license provision was deleted; the current text contains one vestige of the original provision, the statement in Article 2(8) that "The Protection of the Convention shall not apply to news of the day or to miscellaneous facts having the character of mere items of press information.” See Sam Ricketson, The Berne Convention for the Protection of Literary and Artistic Works: 1886-1986 302-06 (1987). 